IZA DP No. 4539

Does Self-Employment Increase the Economic Well-Being of Low-Skilled Workers?

Magnus Lofstrom

October 2009 


\title{
Does Self-Employment Increase the Economic Well-Being of Low-Skilled Workers?
}

\author{
Magnus Lofstrom \\ Public Policy Institute of California \\ and IZA
}

Discussion Paper No. 4539

October 2009

\author{
IZA \\ P.O. Box 7240 \\ 53072 Bonn \\ Germany \\ Phone: +49-228-3894-0 \\ Fax: +49-228-3894-180 \\ E-mail: iza@iza.org
}

\begin{abstract}
Any opinions expressed here are those of the author(s) and not those of IZA. Research published in this series may include views on policy, but the institute itself takes no institutional policy positions.

The Institute for the Study of Labor (IZA) in Bonn is a local and virtual international research center and a place of communication between science, politics and business. IZA is an independent nonprofit organization supported by Deutsche Post Foundation. The center is associated with the University of Bonn and offers a stimulating research environment through its international network, workshops and conferences, data service, project support, research visits and doctoral program. IZA engages in (i) original and internationally competitive research in all fields of labor economics, (ii) development of policy concepts, and (iii) dissemination of research results and concepts to the interested public.
\end{abstract}

IZA Discussion Papers often represent preliminary work and are circulated to encourage discussion. Citation of such a paper should account for its provisional character. A revised version may be available directly from the author. 
IZA Discussion Paper No. 4539

October 2009

\section{ABSTRACT \\ Does Self-Employment Increase the Economic Well-Being of Low-Skilled Workers?*}

Low-skilled workers do not fare well in today's skill intensive economy and their opportunities continue to diminish. Given that individuals in this challenging skill segment of the workforce are more likely to have poor experiences in the labor market, and hence incur greater public expenses, it is particularly important to seek and evaluate their labor market options. Utilizing data from the Survey of Income and Program Participation, this paper provides a comprehensive analysis of the economic returns to business ownership among low-skilled workers and addresses the essential question of whether self-employment is a good option for low-skilled individuals that policymakers might consider encouraging. The analysis reveal substantial differences in the role of self-employment among low-skilled workers across gender and nativity - women and immigrants are shown to be of particular importance both from the perspectives of trends and policy relevance. We find that although the returns to low-skilled self-employment among men are relatively high we find that wage/salary employment is a substantially more financially rewarding option for most women. These findings raise the question of why low-skilled women enter self-employment. Our business start-up results are consistent, but not conclusive, with lack of affordable child care options and limited labor market opportunities in the wage/salary sector as motivating native born women to enter self-employment. We do not find empirical evidence of similar constraints among immigrant women.

JEL Classification: J15, J16, J31, L26

Keywords: $\quad$ self-employment, entrepreneurship, low-skill, women, immigrants

Corresponding author:

Magnus Lofstrom

Public Policy Institute of California

500 Washington Street

Suite 600

San Francisco, CA 94111

USA

E-mail: lofstrom@ppic.org

* I thank Robert Fairlie, Hans Johnson, David Neumark and Claudia Viek for helpful comments on earlier drafts. 


\section{Introduction}

The number of self-employed has steadily increased in the U.S. over the last decades, from roughly 9.9 million in 1980 to approximately 17.3 million in $2007 .{ }^{1}$ The strong growth is partially responsible for the common perception that self-employment and small businesses are engines of growth in the economy. Importantly, self-employment is frequently viewed as a route to upward economic mobility. This is particularly relevant for workers with low educational attainment, workers with no more than a high school diploma. Whether self-employment should be encouraged by self-employment assistance policies depends on a number of factors related to the expected economic contributions of entrepreneurs, including how it affects their earnings and whether there is evidence of business start-up barriers and possible other inefficiencies in the labor market. In this paper we address the fundamentally important issue of whether selfemployment is an economically rewarding option for low-skilled workers. In doing so, we also look for evidence of constraints which may limit low-skilled individuals’ labor market opportunities.

Low-skilled workers have not fared well in the labor market and opportunities continue to diminish. For example, data from the Current Population Survey show that in 1975, the annual earnings of college graduates was slightly more than four times the annual earnings of workers without a high school diploma. By 2006, the college graduates' earnings advantage had grown to approximately 6.6 times the earnings of high school dropouts. Employment rates among men without a high school diploma have also fallen in the last few decades. Raphael (2008) reports that the employment rate of white male dropouts in 1980 was 75 percent but by 2000 the employment rate for this group had dropped to 61 percent. He also observes large drops in the employment rates of male minority dropouts. Women without a high school diploma did not experience a substantial drop in the employment rate but the difference in employment between female college graduates and dropouts increased between 1980 and 2000.

Clearly, low-skilled workers face limited labor market opportunities in today’s skill intensive economy. Beyond the concern of the economic well-being of less skilled workers and

\footnotetext{
${ }^{1}$ We use the terms self-employed, entrepreneur and business owner synonymously.
} 
their families, policy makers are also worried by the associated greater social economic costs. Workers with lower skills and less education earn less, are more likely to be unemployed and on welfare than workers with at least some college education. These are just some examples of the negative outcomes associated with lower skills.

Identifying policy tools capable of improving labor market outcomes of low-skilled workers is undoubtedly important. An effort to increase skills (including formal schooling, vocational training and English courses for English learners) is one option likely to improve the economic well being of low-skilled workers. However, it may be difficult to entice individuals to participate in such programs. This is likely to be particularly difficult among low-skilled working age adults, most who have not been in school for years and many who face the constraint of being bread winners in the family.

Although entrepreneurship is promoted by state and federal policies as well as numerous non-profit organizations, we know very little about self-employment among low-skilled workers. In this paper, we address the question of whether self-employment should be considered a policy tool to broaden the labor market alternatives of individuals with only a high school diploma or less. However, before policies designed to assist workers in this challenging segment of the skill distribution who are contemplating entry into self-employment are implemented or expanded, we need to explore evidence of the degree of success realized by those choosing self-employment -what kinds of earnings expectations are realistic and how do they compare to those of similar workers in regular employment? For targeting purposes, it is also important to identify factors associated with earnings success, or possibly, lack-thereof, among present and potential lowskilled entrepreneurs.

The objective of this paper is to assess whether self-employment is an economically rewarding option for low-skilled workers. To do so, we analyze and compare the earnings and earnings growth of low-skilled business owners to those of low-skilled workers in regular employment. The results raise the question of why individuals in some groups, particularly women, enter self-employment. In an effort to shed light on this issue, we examine potential barriers to low-skilled entrepreneurship. 


\section{Previous Research}

The economic returns to self-employment have previously been rather extensively examined. Studies from the 1980s find that potential wages and wage growth of entrepreneurs are higher or not significantly different from the wages and growth of paid employees (for example, Brock and Evans, 1986; Rees and Shah, 1986 and Evans and Leighton, 1989). However, in Hamilton's (2000) seminal paper he finds that most entrepreneurs have both lower initial earnings and lower earnings growth than they would receive in paid employment. He finds that earlier results indicating relatively high returns to self-employment may be influenced by a handful of high-income entrepreneurial "superstars". The observed higher average earnings may thus not characterize the self-employment returns of most business owners. He also points out that previous studies relied on data which lacked important information on the length of time in business. These issues are recognized and addressed in this paper.

The self-employment entry literature is also relevant to this research. A major focus of this strand of the entrepreneurship research is on the role of access to financial capital in business creation and whether liquidity constraints are binding. This is often assessed by investigating whether individual's own financial wealth impacts the decision to become a business owner, holding other relevant factors constant. These studies typically find evidence of binding liquidity constraints in business start-ups (e.g. Evans and Leighton, 1989; Evans and Jovanovic, 1989; Lindh and Ohlsson, 1996). An exception is Hurst and Lusardi (2004) who only find a positive relationship between wealth and business entry at the top of the wealth distribution. Furthermore, Holtz-Eakin, Joulfaian and Rosen (1994a) find that greater assets, measured as inheritances, lead to a higher probability of business survival, again suggesting that liquidity constraints are binding and not only affects business start-ups. Moreover, Bates (1990) finds that owner educational background is a major determinant of both business survival and the financial capital structure of small business start-ups. Other factors linked to the self-employment entry decision include managerial ability (e.g. Jovanovic, 1982) risk aversion (e.g. Kihlstrom and Laffont, 1979), non-pecuniary benefits of owning one’s business (e.g. Blanchflower and Oswald, 1998) and intergenerational links, including parental wealth (Dunn and Holtz-Eakin, 2000).

These factors have also been linked to explaining low self-employment rates among minority groups, particularly African-Americans. Although differences in household net worth, 
education and family structure across groups have been found to partly explain differences in self-employment entry and exit rates (Fairlie, 1999; Hout and Rosen, 2000), differences in parental entrepreneurship and intergenerational self-employment links appear to explain a significant proportion of the gap (Fairlie, 1999 and Hout and Rosen, 2000).

Surprisingly, existing research on low-skilled self-employment, and the performance of lowskilled entrepreneurs, is scant. Exceptions include two papers by Robert Fairlie (2004 and 2005). In these papers he analyzes earnings of disadvantaged entrepreneurs, based on both parental education and the individual's education. Fairlie (2004) studies young less-educated business owners and finds that after a few initial years of slower growth, the average earnings for the selfemployed grow faster over time than the average earnings for wage/salary workers. Fairlie (2005) defines disadvantaged differently and focuses on family background (parents' education). He finds some evidence that disadvantaged self-employed business owners earn more than wage/salary workers from disadvantaged families. Also relevant is Holtz-Eakin, Rosen and Weathers (2000). They analyze possible links between entrepreneurship and earnings mobility and find that low-income self-employed individuals moved ahead in the earnings distribution relative to those who remained in wage/salary work.

This paper contributes to the limited existing research on low-skilled entrepreneurship in several ways. First, unlike Fairlie’s studies, we do not restrict our analysis to young workers (ages 22 to 39) but include individuals of all working ages (defined here to be ages 18 to 64). We also separately analyze earnings growth among foreign and U.S. born workers. Like Fairlie (2005) but unlike Holtz-Eakin, Rosen and Weathers (2000), we identify earnings growth effects

utilizing individual fixed effects models, which account for individuals’ differences in important time invariant factors such as ability and motivation. Furthermore, in an effort to present a comprehensive study of the economic returns to low-skilled business ownership, the paper also provides the first analysis of low-skilled self-employment entry.

\section{Trends in Low-Skilled Self-employment}

We begin our analysis by providing a brief overview of low-skilled self-employment prevalence and trends in the U.S. As mentioned above, business ownership grew substantially 
over the last few decades - Overall, the total number of self-employed individuals increased by more than 7 million between 1980 and 2007. A closer look at the data reveals that over this period the composition of business owners changed quite substantially in a number of ways and that women and immigrants play increasingly important roles. These trends can be gleaned from Tables 1 and 2, where we present the number of self-employed individuals and self-employment rates by skill, gender and nativity

First, female self-employment is a significant source of the growth in business ownership. Quite remarkably - given the lower albeit increasing female labor force participation rate slightly less than half of the increase in the number of self-employed from 1980 to 2007 are women. About 3.5 million more women report being self-employed in 2007 compared to 1980. The increase for men over the same period was 3.9 million. As a result, although women represented slightly less than 24 percent of the total number of self-employed workers in 1980, they now represent 36 percent.

Second, the skill composition of business owners has changed. In 1980, 58 percent of business owners had no more than a high school diploma. This group of low-skilled entrepreneurs now represents about 40 percent of self-employed Americans. Although the latter shows that the country's entrepreneurs are more skilled today than they were in previous decades it masks - due to the overall increase in educational attainment - the fact that low-skilled individuals are more likely to choose self-employment today than they were 25 years ago. This is particularly true for women for whom the low-skilled self-employment rate increased from 3.9 percent in 1980 to 6.9 percent in 2007. Among low-skilled men the self-employment rate also increased, from 10 percent to 11.3 over the same period. While the male college graduate selfemployment rate is quite high, men in this skill group are less likely to choose self-employment in 2007 (14.5 percent) than they were in 1980 (15.2 percent). However, among female college graduates, the self-employment rate increased from 5.1 percent in 1980 to 8.3 percent in 2007.

Third, foreign born entrepreneurs play an increasingly important role. In 1980, approximately 7 percent of the self-employed were foreign born. In 2007, slightly more than 21 percent were born abroad, significantly above the 13 percent foreign born share of the population in the U.S. The data show that the number of U.S born self-employed individuals increased by slightly more than five million over this period while the number of self-employed immigrants increased by about 2.3 million. While the growth in native born self-employment was exclusively among 
individuals with at least some college training, low-skilled self-employment dominates the increase in immigrant entrepreneurship. Roughly one-half of the increase in foreign born selfemployment was from low-skilled self-employment.

Importantly, these data show that the entire growth in low-skilled self-employment is due to immigrant entrepreneurs. In fact, there are fewer native born low-skilled today compared to 1980. 2 The decline in the number of low-skilled U.S. born business owners is due to the overall increase in educational attainment. ${ }^{3}$ This is evident from the observation that the selfemployment rate for both native born low-skilled men and women increased from 1980 to 2007, from 10.1 to 11 percent and 3.9 to 6.1 percent respectively for men and women. The selfemployment rate among the low-skilled foreign born population increased over the same period from 9.8 to 10.5 percent and 4.2 to 10.6 percent for men and women respectively. It is clear from this that self-employment now plays a particularly important role among low-skilled immigrants, especially foreign born women who are now slightly more likely to be self-employed than foreign born men.

The above descriptive statistics show that low-skilled business owners are an important source of the growth in self-employment in the U.S., particularly among women and immigrants and that the low-skilled self-employed represent a sizeable share of the state's entrepreneurs. The current (as of 2007) total number of low-skilled entrepreneurs is approximately about 6.9 million, a greater number than that of business owners with at least a college degree, 5.6 million. The labor market performance of the large number of self-employed workers with low schooling levels is clearly of interest.

\section{Comparing Earnings of the Self-Employed and Wage/Salary Workers}

The main objective of the paper is to assess the relative success of low-skilled entrepreneurs compared to low-skilled wage/salary workers. The measures of success used are based on total annual earnings because these outcome measures closely reflect the overall economic well being of individuals.

\footnotetext{
2 Table 1 shows that although the number of low-skilled native born women increased, it decreased by more among native born men.

3 The decrease in the low-skilled labor force participation rate may also contribute the decline in low-skilled native born entrepreneurs.
} 
An important issue to consider when comparing earnings between self-employed and wage/salary workers is the fact that self-employment earnings do not only represent returns to human capital but also returns to financial capital invested in the business. That is, reported selfemployment earnings partially reflect a return to owner investments made in the business while wage/salary earnings do not. In addition to using total annual earnings, we therefore generate two additional earnings measures. The first simply adds to annual earnings annual asset income received from financial capital, i.e. stocks, bonds, real estate and other investments, which is observed for both the self-employed and wage/salary workers. Total annual earnings and capital income is hence an income measure that includes returns to physical and financial capital for self-employed individuals as well as workers in wage/salary employment.

A second alternative approach entails subtracting a portion of the earnings of the selfemployed, which roughly represents owner returns to investments of resources - cash, inventory, equipment, and the like, net of debt -- in their small businesses. Hence, we utilize the reported dollar amount of business equity information available in our data (discussed below) and subtract from annual earnings an amount equal to five percent of this business equity, representing an inflation adjusted real return to a relatively risky investment. Use of the five percent figure is a reflection of the opportunity cost of capital. By assumption, alternative investments into which this business equity dollar amount could be deployed would be expected to earn a five percent real rate of return, roughly equivalent of a nominal return of eight to nine percent. By way of example, an owner reporting a \$50,000 business equity amount, along with annual net profits of $\$ 40,000$, would be assumed to have earned $\$ 2,500$ as a return on her/his business equity investment. The balance - profits of $\$ 37,500$ - is attributed to the owner's returns for time spent working in her small business. We refer to this measure as "business equity-adjusted" earnings, which we interpret as an income measure that reflects only returns to human capital for both employed workers and the self-employed.

Although we argue above that the use of a five percent real discount rate is reasonable in this setting, clearly the specific choice of a return to business equity to subtract from the reported annual earnings is ad hoc. The impact of alternative returns is that a higher interest rate leads to lower business equity adjusted earnings while a lower discount rate leads to more favorable comparison for the self-employed (a zero discount rate generates a measure identical to our total annual earnings measure). Lastly, we note that the use of an assumed real return of five percent 
is similar to Fairlie's (2004) approach and that given the relatively low levels of business equity among low-skilled entrepreneurs, the results are not sensitive to minor changes in the assumed discount rate, nor do we find that the conclusions in this report are sensitive to the earnings measure utilized.

\section{Data}

We use nationally representative individual longitudinal data from the 1996, 2001 and 2004 panels of the U.S. Census Bureau's Survey of Income and Program Participation (SIPP). The SIPP data contain individual demographic information as well as detailed information on labor market activities, business ownership and business characteristics.

The surveys are conducted every four months (representing a "wave") for, depending on the panel, roughly 37,000 to 47,000 U.S. households in each panel. The length of the panel is four years for the 1996 and 2004 panels while the 2001 panel followed individuals for only three years. Importantly given the focus on disadvantaged groups, SIPP panels over-sampled lowincome households. The data are nationally representative when the provided sampling weights are used. Each wave in the SIPP panels contain both core questions, common to each wave, and topical questions that are not updated in each wave. In addition to the key variables found in the core modules, we use information from two topical modules; immigration (which includes information on country of origin, citizenship status and year of arrival, collected in the 2nd wave in each panel) and assets and liabilities (containing wealth and asset data, including business equity, collected once a year in each panel). ${ }^{4}$

The sample utilized is restricted to low-skilled individuals, men and women, between the ages of 18 and 64 in the survey period. We do not restrict our sample to only full-time working individuals since a significant proportion of business entries are from non-employment. We do however exclude individuals who were enrolled in school all periods observed. Furthermore, we restrict our sample to individuals for whom immigration status and wealth information are available and who are observed at least over a one-year period. The latter restriction is necessary for our analysis of transitions into self-employment, which is based on changes in year-over-year

\footnotetext{
4 Although the 2004 Panel was originally set to have 12 waves with a full set of topical modules, due to budget constraints, the topical modules were not collected for waves 9-12. Furthermore, the sample was cut by half for this time period.
} 
labor market state, as well as our earnings analysis relying on an individual fixed effects specification.

We define an individual to be self-employed if she/he reported owning a business in the sample month and usually working at least 15 hours per week in that business. Similarly, individuals are defined to be wage/salary workers, or employees, if they do not report owning a business but work at least 15 hours per week in their current job. Individuals reporting owning a business but devoting less than 15 hours per week to it are defined to be part-time self-employed. Part-time wage/salary workers are those not owning a business reporting working for less than 15 hours per week in the reference month. We define a person to be unemployed if they reported experiencing at least one week of unemployment during the month and did not satisfy the criteria for being classified as self-employed or a wage/salary worker. A person is defined to be a welfare recipient if they received Supplemental Security Income (SSI), Aid to Families with Dependent Children (AFDC)/Temporary Assistance for Needy Families (TANF) or food stamps and did not satisfy the definition criteria for self-employment, wage/salary work or unemployment. Lastly, survey respondents who do not meet these criteria are defined to be not in the labor force.

\section{Descriptive Statistics}

We start by examining our annual earnings measures to see whether low-skilled entrepreneurs on average earn more or less than wage/salary earners, shown in Tables 3 and 4 . Our data show that low-skilled entrepreneurs have higher average annual earnings than workers in wage/salary employment and that this holds among immigrant and native born men as well as foreign born women. However, female U.S. born business owners earn less on average than U.S. born women wage/salary earners. The magnitude of the differences in average annual earnings depends on the earnings measure. For example, among native born men, the self-employment advantage ranges between approximately one percent (business equity adjusted earnings) and 17 percent (total annual earnings including capital income) while for native born women the selfemployment earnings disadvantage ranges from about three percent (total annual earnings including capital income) and 22 percent (business equity adjusted earnings). Foreign born male business owners earn on average between 13 and 27 percent more than immigrant men in 
wage/salary employment. The corresponding average female self-employment advantage is somewhat lower, between 7 and 12 percent. Although immigrants earn less on average than their native counterparts, the mean earnings differences above indicate that self-employment is a more financially rewarding option for foreign born entrepreneurs than it is for U.S. born business owners.

A comparison of average earnings can be misleading if the success story among entrepreneurs is one of relatively few very successful business owners. A comparison of earnings by selected percentiles reveals that there is truth to this assertion among the low-skilled. The median annual earnings of low-skilled entrepreneurs - U.S. and foreign born men and women are lower than that of low-skilled employees in the same group. ${ }^{5}$ Although the magnitudes of the self-employment disadvantage differ across our three measures, there is no instance in which median earnings are higher among business owners. The comparison of median earnings differences between wage/salary workers and business owners also indicate lower earnings among immigrants than natives. However, the self-employment disadvantage is smaller among immigrants, indicating that self-employment is a relatively more rewarding for the foreign born than it is among the U.S. born, a similar conclusion to the one reached by comparing average earnings.

The observation that the average earnings are higher among low skilled business owners while the opposite is true when median earnings are compared shows the most successful entrepreneurs have higher earnings than the most successful workers in the wage/salary sector. A question that follows is, does this apply to relatively few very successful business owners or are there relatively many entrepreneurs who outperform wage/salary workers? To answer this question we look at and compare the distributions of earnings, or more specifically, selected percentiles of the distributions.

The data reveal that the top 25 percent low-skilled native born male entrepreneurs have higher earnings than the top 25 percent wage/salary workers. Among foreign born men the selfemployment advantage stretches further down in the earnings distribution and approximately the top half of business owners do as well or outperform the top half of wage/salary earners. As

\footnotetext{
5 A look at the overall mean log of total annual earnings difference shows that the total annual earnings of business owners is about 10 percent lower than the earnings of wage/salary workers. The log transformation of total annual earnings reduces the influence of the highest earning individuals. Hence the difference in mean log annual earnings is closely in line with a comparison of median annual earnings.
} 
expected, once self-employment earnings are adjusted for returns to capital invested in the business, self-employment is less rewarding compared to wage/salary work. Nonetheless, both among native and foreign born, the top 25 percent of low-skilled business owners have higher earnings than the top 25 percent of wage/salary earners.

Among U.S. born women we find that only the top 10 percent of entrepreneurs outperform the top 10 percent wage/salary workers. In fact, when we adjust earnings for business equity, native born self-employed women throughout the distribution have lower earnings than their employee counterpart. Low-skilled female immigrant entrepreneurs do somewhat better when compared to immigrant wage/salary workers. The top 25 percent entrepreneurs have roughly the same or higher earnings than their foreign born counterparts who work in the wage/salary sector.

The above descriptive statistics indicate that the economic returns to self-employment are lower for women than men and that they are higher for immigrants than natives. The latter point is important since much of the growth in low-skilled self-employment is among immigrants and that low-skilled immigrants have higher self-employment rates than low-skilled natives. The relative attractiveness of self-employment is one plausible reason for this.

Some of the observed earnings differences between entrepreneurs and employees may not be attributable to self-employment but may be due to differences in earnings relevant demographic traits (such as education, age, family composition, ethnic composition) or workforce characteristics (such as the number of hours worked, previous periods employment status and workforce experience).

A look at differences in the above characteristics between workers in the two sectors, shown in Tables 5 and 6, indicates that differences in these factors do not appear to account for the lower earnings among most low-skilled business owners. Overall, the data indicate that the selfemployed are on average older and work more hours per week than employees. Also, on average, they have been running their businesses longer than wage/salary employees have been at their current job. Entrepreneurs are also under-represented by disadvantaged minority groups such as Hispanics and African-Americans. Among immigrants, the self-employed have been in the U.S. longer than wage/salary workers. These are factors usually associated with higher earnings and hence the descriptive statistics suggest that differences in the observable characteristics do not explain lower earnings among most of the self-employed when compared to wage/salary workers. Our empirical approach, discussed next, will address this and other relevant issues. 


\section{Empirical Model Specifications}

Our objective is to assess the relative success of low-skilled entrepreneurs compared to lowskilled wage/salary workers, where our measure of success is annual earnings. Importantly, we also look for evidence of constraints which may limit low-skilled individuals' labor market opportunities. The latter interest leads to an analysis of self-employment entry.

\section{Total Annual Earnings}

We use ordinary least squares (OLS) to estimate regression models separately for the selfemployed and wage/salary workers by nativity and gender, of the log of total annual earnings. $y_{i t}$, in state $i$ at time $t$. This measure is defined as the log of the sum of wage/salary earnings and selfemployment earnings. The model specification is;

$$
y_{i t}=\mathbf{X}_{i t} \boldsymbol{\beta}+\mathbf{L F S}_{i t-1} \boldsymbol{\delta}+\varepsilon_{i t}
$$

where

$$
\begin{aligned}
& \mathbf{X}_{i t} \quad=\quad \text { Matrix containing individual characteristics such as age, educational } \\
& \text { attainment, marital status, family composition, geographic location and } \\
& \text { ethnicity. }
\end{aligned}
$$

The use of lagged labor force status in our earnings model deserves some justification. These controls are included to reduce omitted variable bias of parameters of interest. Put differently, these controls are intended to purge the data of the impact of previous labor market outcomes or decisions on earnings. Furthermore, since repeated individual observations are not assumed to be independent, all estimates are clustered on individuals.

We also estimate individual fixed effects models to obtain estimates of the impact of years in business or years at current job. In this specification, we do not include lagged labor force status, since it is time invariant for certain sub-groups, including all individuals who stayed 
in business or remained in the same job for the full sample period. We do however include a control for hours worked per week. It is also possible to include additional controls for variables that may change over time, such as family composition and geographic location. However, the estimated coefficient of these variables are unlikely to represent causal impacts since they are identified through variation in the arguably selective sub-sample for whom these variable values change. Furthermore, including these variables do not appreciably affect the years in business or job parameters. Hence, we opted for presenting the results for the more parsimonious specification.

Lastly, since the analysis is based on a sample in which individuals are not randomly assigned to different labor market states, and that due to no available credible instruments, we do not model the selection into these groups, the presented estimates are not clearly causal. To minimize endogeneity concerns, we go beyond much of the existing literature and use model specifications intended to address some of these concerns, such as including controls for work history and controlling for time invariant individual unobserved heterogeneity.

\section{Self-Employment Entry}

The self-employment entry probability is defined to be the probability of entering selfemployment at time t, conditional on non-business ownership at time $t-1$, where time $t$ is measured in years. We only utilize one observation per year for each individual. There are a number of reasons for this, including the fact that many independent variables are time invariant, or close to. Also, of great interest in our analysis is the role of financial capital, here represented by wealth and asset information, which is only collected once a year, in waves 3, 6, 9 and 12 (if applicable).

To model the decision to enter a business venture we assume that individuals choose to enter self-employment based on expected utility in each state (e.g. self-employment, wage/salary work, unemployment or to not participate in the labor force), as well as constraints faced by the individual.

Let us assume that the utility function is a function of expected income, or earnings if working, $y_{\mathrm{it}}^{\mathrm{s} \text {-e }}$ for self-employment work and $y_{\mathrm{it}}^{\mathrm{J}}$ for participating in state $\mathrm{J}$ (defined here as wage/salary work, unemployment or to not participate in the labor force and where $i$ and $t$ are indices for individual $i$ at time $t$ ). Furthermore, earnings, or income, in each state will depend on 
a vector of observable characteristics, $\mathbf{X}_{i t}$, possible constraints faced by the individual, $\mathbf{v}_{i t}$, and unobserved characteristics $\varepsilon_{i t}$, which may represent random shocks to earnings or income opportunities and/or information known to the individual but not to the econometrician. Assuming that individuals maximize expected utility, a person will choose self-employment if the expected utility from self-employment, denoted $E\left(u_{\text {it }}^{\text {s-e }}\right)$, is greater than the expected utility in any of the other $\mathrm{J}$ states, represented here by $E\left(u_{\mathrm{it}}^{\mathrm{J}}\right)$. Expected utility in the $\mathrm{J}+1$ states can be defined as:

$$
\begin{aligned}
& E\left(u_{i t}^{J}\right)=y_{i t}^{J}+\mathbf{v}_{i t}^{J} \delta^{J}+\varepsilon_{i t}^{J}=\mathbf{X}_{i t} \beta^{J}+\mathbf{v}_{i t}^{J} \delta^{J}+\varepsilon_{i t}^{J} \\
& E\left(u_{i t}^{s-e}\right)=y_{i t}^{s-e}+\mathbf{v}_{i t}^{s-e} \delta^{s-e}+\varepsilon_{i t}^{s-e}=\mathbf{X}_{i t} \beta^{s-e}+\mathbf{v}_{i t}^{s-e} \delta^{s-e}+\varepsilon_{i t}^{s-e}
\end{aligned}
$$

where $\varepsilon^{J}$ and $\varepsilon^{s-e}$ may be assumed to be jointly normally distributed with mean zero and variances $\sigma_{J}^{2}$ and $\sigma_{s-e}^{2}$. Alternatively, as is done in our analysis, the disturbances may be assumed to follow a logistics distribution. An individual chooses self-employment at time $t$ if:

$$
I_{i t}^{*}=E\left(u_{i t}^{s-e}\right)-E\left(u_{i t}^{J}\right)>0, \text { for any state } \mathrm{J}
$$

Clearly the index function $I_{i t}^{*}$ is unobservable. However, from equations (1), (2) and (3) $I_{i t}^{*}$ can be defined as:

$$
\begin{aligned}
I_{i t}^{*} & =E\left(u_{i t}^{s-e}\right)-E\left(u_{i t}^{J}\right) \\
& =\mathbf{X}_{i t} \beta^{s-e}-\mathbf{X}_{i t} \beta^{J}+\mathbf{v}_{i t}^{s-e} \delta^{s-e}-\mathbf{v}_{i t}^{J} \delta^{J}+\varepsilon_{i t}^{s-e}-\varepsilon_{i t}^{J} \\
& =\mathbf{W}_{i t} \pi+e_{i t}
\end{aligned}
$$

If we set $I=1$ if $I_{i t}^{*}>0$, if the individual is observed to have entered self-employment at time $t$, and $I=0$ if $I_{i t}^{*} \leq 0$, if the person decides not to start up a new business, then equation (4) can simply be seen as a probability model of entry into self-employment. In other words, the model can be seen as a conditional probability model where the person is observed to be not selfemployed in the previous time period, i.e. at $t-1$.

The entry models estimated can then be represented by the following, where $I_{i t}=1$ represents an observed transition, i.e. a decision to enter self-employment:

$$
\operatorname{Prob}\left[I_{i t}=1\right]=\mathbf{X}_{i t} \beta+\mathbf{L F S}_{i t-1} \gamma+\mathbf{v}_{\text {it }} \delta+e_{\text {it }}
$$

where 


$$
\begin{array}{ll}
\mathbf{X}_{i t}= & \text { Matrix containing same controls as earnings models } \\
\mathbf{L F S}_{i t-1}= & \text { Matrix containing same controls as earnings models } \\
\mathbf{v}_{i t}= & \text { Matrix containing controls for potential business ownership constraints, } \\
& \text { or barriers, such as financial assets (and previous year's labor market } \\
& \text { status). We use lagged household net worth (entry) as proxies for financial } \\
& \text { capital constraints. }
\end{array}
$$

We estimate all models separately for the U.S. and foreign born by gender. To address possible endogeneity concerns of wealth on self-employment, in the sense that higher wealth levels may be the results of entrepreneurship and not the cause, we utilize one year lagged wealth information in the estimated models. Since repeated individual observations are not assumed to be independent, all estimates are clustered on individuals.

\section{Empirical Results}

The earnings regression results show, as expected, that factors like age, education, experience and hours work have positive impacts on earnings, shown in Tables 7 and 8. Although the minority earnings disadvantage differ across the two sectors, the results consistently show lower earnings among African-Americans and Hispanics. Above, we also pointed out that on average low-skilled business owners are older, work more hours per week than employees and that they have been running their businesses longer than wage/salary employees have been at their current job. We also noted that minorities are underrepresented among business owners. These observations suggest that differences in observable characteristics do not explain the unadjusted lower median and mean log annual earnings of low-skilled business owners.

To more specifically analyze how observable earnings related factors affect the earnings differences between wage/salary workers and the self-employed we use Oaxaca earnings decompositions. To do so, we use the regression estimates in Tables 7 and 8 and the sample means in Tables 2 and 3 to determine how much each observable factor contributes to the mean log earning gaps. This exercise, results shown in Table A1, clearly reveals that differences in the 
observable characteristics do not explain lower earnings among most of the self-employed when compared to wage/salary workers.

Overall, the data and our analyses indicate that most low-skilled business owners have lower earnings than those of workers in the wage/salary sector. This is reinforced by the observation that the entrepreneurs are more likely to possess characteristics, workforce background and skills associated with higher earnings. In other words, the self-employment earnings disadvantages are greater once these factors are considered. It naturally follows to ask the question: If low-skilled entrepreneurs typically have lower earnings than wage/salary earners, why chose self-employment? There are a number of plausible reasons, such as preferences for work autonomy and flexibility, wanting to be one's own boss and the lure of high earnings. The latter appears plausible since top entrepreneurs earn more than top wage/salary workers but it is also possible that the long-term benefits of business ownership are attracting workers. To address this issue, we analyze earnings growth to investigate whether the prospect of expected higher future earnings may motivate individuals to start their own business.

To account for individuals’ differences in important unobservable earnings related factors that are assumed to not change over time, such as ability and motivation, we obtain the necessary estimates to identify earnings growth by using individual fixed effects specifications. 6 This implies that any estimated earnings growth differences between low-skilled entrepreneurs and wage/salary workers is not due to the possibility that one group consists of more motivated or able individuals than the other. We use these estimates, presented in Tables A2 and A3, to explore the following earnings scenario of two hypothetical individuals in each group - one who just started her/his own business and the other who instead of entering self-employment started a new job in the wage/salary sector.

The results of this exercise, shown in Figures 1 and 2, provide evidence that in the longrun low-skilled men do relatively well compared to low-skilled employees and especially among foreign born men. Our results show that the earnings of men who just started their business is lower compared to wage/salary workers who just started a new job, approximately eight and two percent lower respectively for native and foreign born men. Interestingly, and similar to Fairlie (2004), the estimates also show that the earnings gap increases during the immediate following

\footnotetext{
6 For each group we performed F-tests to determine the appropriate functional form of earnings growth. The best fits appear to be either a second or third order degree polynomial.
} 
years and peak after about five years at about 14 and 10 percent among U.S. born and immigrant men respectively. However, the results also illustrate that earnings increase somewhat faster in the subsequent years for self-employed men and are roughly equal after about 10 years among immigrant men and after about 13-14 years for native born men.

Low-skilled female entrepreneurs do not do as well as men when compared to wage/salary earners. We find no evidence that earnings growth is greater among female business owners than among women working in wage/salary work. Native born women start out at lower earnings and even in spite of substantial earnings growth there is no evidence that their earnings will reach the levels of wage/salary earners. The differences are smaller among low-skilled immigrant women but the results show that female immigrant entrepreneurs continue to have lower earnings in the long-run.

Lastly, we note that the earnings growth analysis to some extent overstates the performance of business owners since we have not applied any discounting of the returns to financial capital to our analysis. However, the typically relatively low levels of business equity among low-skilled entrepreneurs suggest that the potential upward bias of their performance is likely to be comparatively minor. Our analysis using our business equity adjusted earnings measure supports the latter but also indicates a relatively less favorable comparison for the selfemployed. 7

\section{Why Do Low-Skilled Women Enter Self-Employment?}

The above analysis of earnings provides a clear picture of substantial differences between low-skilled men and women in the success as entrepreneurs. The economic returns, both in the short- and long-term, to self-employment among women are considerably lower than the returns to business ownership among men. This is true for foreign born women but especially for U.S. born women. The low pecuniary return to business ownership among low-skilled women raises the question of why low-skilled women enter self-employment. An examination of business start-up rates and associated determinants can shed light on this.

Low-skilled men are more likely to enter self-employment than low-skilled women and the difference is greater among the U.S. born. Tables A4 and A5 show that immigrants are more

\footnotetext{
7 The results are not included but are available upon request from the author.
} 
likely to enter self-employment than natives. The year-to year native self-employment entry rate is 2.6 and 2.0 percent respectively for men and women while among immigrants the business start-up rate is 3.1 and 2.7 percent for men and women respectively. Among native born, men are approximately 30 percent more likely to enter self-employment than women. The gender difference is about half, or 15 percent, among immigrants. The lower returns to self-employment among women, especially among native born females, may well be a reason for these differences.

The issue of why women opt for starting their own business was raised earlier and nonpecuniary reasons, such as work autonomy and flexibility were given as possible reasons. Women, particularly mothers of young children, may chose self-employment for these reasons, and more so than men. If these are indeed the main or common motivations for women to become self-employed, there may be fewer reasons to be concerned about the low economic returns to female self-employment. This conclusion hinges on the assumption that affordable and quality child care is widely available. However, this may not be the reality for many low-skilled women. Importantly, if few and poor child care options is the main reason for women opting to run small businesses, as opposed to working in the more financially rewarding wage/salary sector, the policy focus should be on child care solutions, as opposed to self-employment assistance.

There is some evidence in support of the notion that child care may be a relevant issue in explaining the low economic returns to self-employment among women. We observe that among self-employment entrants there is a higher proportion women with young children than there is among male entrants, shown in Tables A4 and A5 show. We also find that some self-employed women with young children have lower earnings than otherwise observationally identical entrepreneurs without children. 8 The negative relationship between young children and earnings is weaker among female workers in the wage/salary sector but is stronger than it is among male business owners. Combined, these observations are consistent with the hypothesis that some women may have made a trade-off forsaking higher earnings for non-pecuniary benefits, in selecting self-employment over wage/salary work, but it is not conclusive evidence. ${ }^{9}$ The data do not allow us to directly investigate whether this choice is related to limited child care options or

\footnotetext{
8 The analysis here is based on the earnings regression estimates presented in Tables 7 and 8.

9 The lack of conclusiveness is partly due to the relative imprecision of the regression estimates.
} 
if women who have children simply want to devote more time with their children and subsequently choose self-employment because of the flexibility that it affords. However, it is not clear that many low-skilled women, who live in household with incomes below or near poverty levels, can afford to deliberately make a choice which is likely to lead to lower earnings.

Nonetheless, trouble finding child care solutions may not be an important reason why women become self-employed. After all, many of the low-skilled women who own businesses do not have children. Limited opportunities on the low-skilled wage/salary sector may instead be an explanation. The self-employment literature refers to "push" factors when individuals decide to start businesses when no other attractive alternatives are available. Higher economic returns and non-pecuniary benefits of business ownership are, on the other hand, called "pull” factors. It may be that women become self-employed due to push factors to a greater extent than men.

Men and women who enter self-employment differ in several dimensions. ${ }^{10}$ For example, while more than half of male native self-employment entrants come from the wage/salary sector only slightly more than $1 / 3$ of women enter from this sector. There is a higher proportion of women who enters from part-time work, and especially from non-employment (unemployment, on welfare participation or not in the labor force), compared to men. Close to 40 percent of U.S. born women who enter self-employment do so from non-employment while only about 26 percent of native men enter from non-employment. More than half of foreign born women who start a new business come from non-employment. The corresponding proportion among immigrant men is about 33 percent.

It is plausible that the stark gender differences in previous labor market status and labor market experience are important factors contributing to the lower female self-employment earnings, relative to male entrepreneurs. In fact, the empirical earnings results do provide evidence that these factors contribute to the gender earnings gap. Approximately $1 / 3$ of the immigrant and $1 / 4$ of the native gender self-employment earnings gap can be explained by women's less favorable workforce experience. ${ }^{11}$

\footnotetext{
10 Tables with descriptive statistics of potential self-employment entrants can be found in the Tables A4 and A5. 11 We use the earnings regressions estimates in Tables 7-8 and the descriptive statistics in Tables 5-6 to calculate the contribution of these factors on gender differences in the self-employment earnings.
} 


\section{Analyzing the Business Start-Up Decision}

The substantial gender differences in employment background may also have direct consequences regarding gender differences in start-up rates. We next explore individual start-up factors and the role they play in an effort to explain differences in the reasons why men and women enter self-employment. To do so, we estimate self-employment entry logit models to look for factors that are associated with the probability of business start-up, such as family composition and previous labor market experience, and how these factors may explain selfemployment differences between men and women. The marginal effects from the estimated logit models are shown in Table 9.

The regression results show that factors such as age and previous labor market experience, and to some extent family composition, are associated with the probability of self-employment entry. Furthermore, we also find that for native born women, but not for the other groups, higher levels of household net worth are associated with a higher probability of entry into selfemployment. Although the estimates are marginally statistically significant, this finding is consistent with some low-skilled women facing limited access to business start-up capital.

The lack of evidence of binding capital constraints as an important factor limiting businesses start-ups among potential entrepreneurs is contrary to some previous research findings (for example, Evans and Jovanovic, 1989 and Bates, 1997). However, the results in this report are in line with more recent research. Lofstrom and Wang, (forthcoming) show that the relationship between household wealth and self-employment entry is limited to so-called high barrier industries, such as finance/insurance/real estate, manufacturing and professional services, which require relatively more start-up capital. These are industries which few low-skilled workers enter and instead, low-barrier industries, such as gardening/landscaping, personal services and repair services, are the most relevant industries for low-skilled would be business owners.

We next use the entry regression estimates in an empirical exercise to attribute how much of the gender differences in factors such as these, help explain gender differences in business startup rates. ${ }^{12}$ We find that they are generally of minor importance. Women are more likely to be non-employed than men and since these factor are positively associated with the probability of business start-up, gender differences in non-employment rates do not help explain why women

\footnotetext{
12 The results of the gender entry decomposition analysis are not presented but available upon request.
} 
are less likely to enter self-employment than men. Furthermore, we do not find evidence that gender differences in other potentially relevant factors such as age, ethnic composition or job experience contribute to the lower female start-up rates.

It is plausible that is not the gender differences in the above characteristics that will shed light on the reasons why women enter self-employment in spite of low economic returns but that instead it is differences in how these factors impact the business start-up rates that provides relevant information. This suggests that a closer look at the estimated effects is of interest. Among native born workers, the estimates suggest that women with young children are more likely to enter self-employment than men with young children. Empirical evidence supporting this is weaker for low-skilled immigrant women.

If limited opportunities in the wage/salary sector, so called push factors, are important reasons for women choosing self-employment, it is reasonable to expect women to be more likely to start a business while experiencing non-employment than otherwise observationally similar men. On the other hand, barring wage/salary entry constraints, the relatively higher earnings in the wage/salary sector should lead women to being less likely to start their own business than observationally similar unemployed men. This may be particularly relevant for individuals who were unemployed the previous year since this labor market state implies actively seeking employment (and is a labor market state associated with many start-ups). The selfemployment entry estimates show that unemployment does increase the probability of a business start-up more among U.S. born women than men but we do not find empirical evidence that this holds among immigrants.

The empirical results are consistent with lack of affordable child care options and limited labor market opportunities in the wage/salary sector motivate U.S. born women to enter selfemployment. However, we do not find empirical evidence of similar constraints among immigrant women. We next turn to a summary and discussion of the policy relevance of these and our other findings.

\section{Summary and Conclusions}

Self-employment has grown steadily over the last few decades in the U.S. This paper shows that women and immigrants play important roles in this growth but they do so in different 
skill segments. Among college graduates, U.S. born women accounted for the greatest increase in the number of business owners while immigrant men contributed the greatest boost to the number of low-skilled entrepreneurs. Although the self-employment rate of low-skilled native born increased over this period, the data reveal that all of the net increase in the number of lowskilled business owners is due to immigrants. We also show that today there are more low-skilled business owners than there are entrepreneurs with a college degree.

Recognizing the limited labor market opportunities for low-skilled workers, we address the question of whether self-employment should be considered a policy tool to broaden the labor market alternatives of individuals with low schooling levels. Policymakers may want to consider encouraging self-employment as a policy tool to increase the economic well being of low-skilled workers, if self-employment brings earnings on par with earnings in the wage/salary sector and/or if there is evidence of barriers to self-employment entry (presumably due to market inefficiencies, such as limited access to business start-up capital). It is also possible that encouraging self-employment is desirable if there is evidence that low-skilled workers face difficulty finding employment in the wage/salary sector, and that such barriers are difficult to remove through public policies.

Our earnings analysis reveals that the earnings of most low-skilled workers is higher in wage/salary employment than self-employment but also that top earning entrepreneurs have higher earnings than top earning wage/salary workers. The research makes clear that the economic returns to self-employment among low-skilled individuals are different for men and women. Among men, it is a relatively financially rewarding employment option leading to similar or higher earnings to those in wage/salary employment, particularly among immigrants. The economic return to self-employment is a plausible factor attracting low-skilled men to business ownership. We do not find evidence that low-skilled potential male entrepreneurs are hampered in the start-up efforts by lack of available financial capital.

The economic rewards to self-employment among low-skilled women are lower than those among low-skilled men. We find that wage/salary employment is a substantially more financially rewarding option for most women. The lower return among female business owners is partly due to less favorable previous labor market experiences, many enter from nonemployment. However, even accounting for less favorable workforce experience, the economic 
gains to entrepreneurship are low, which raises the question of why low-skilled women choose self-employment over wage/salary employment.

Focusing on child care availability and limited opportunities in the wage/salary sector as possible motivations for self-employment entry, we examine whether presence of young children and non-employment play a role. Among native born workers, we find evidence that women with young children are more likely to enter self-employment than men with young children. The empirical analysis also shows that unemployment increases the probability of a business start-up more among U.S. born women than men. Although not conclusive, the results suggest that lack of affordable child care options and limited labor market opportunities in the wage/salary sector motivate low-skilled women to enter self-employment. Empirical evidence supporting this is weaker for low-skilled immigrant women.

Encouraging self-employment among low-skilled women may not increase the economic well-being of most women. The finding that limited child care options may be a barrier to entry into the wage/salary sector suggests that policies leading to an increase in affordable child care may have beneficial economic effects on low-skilled women. Although it is difficult to envision how to design policies which would lead to greater work flexibility in the wage/salary sector, such policies could also improve labor market outcomes of women with low schooling levels. The finding that non-employment increases the probability of self-employment entry more among women than men is consistent with women facing more barriers to finding employment in this, more financially rewarding, sector than men. The research in this report, however, does not provide answer to what those specific barriers are. Further research on employment related constraints faced by low-skilled native women is needed.

The empirical results provide no evidence that low-skilled workers are hampered in their efforts to start new businesses due to limited access to financial capital. This conclusion is reached by our finding that individuals from households with greater household wealth are not more likely to enter into self-employment than individuals of similar start-up relevant characteristics but with lower household wealth. This is consistent with recent research and is likely due to the relatively low capital intensity levels of low-skilled businesses (Lofstrom and Wang, forthcoming). An implication is that increasing access to financial capital for low-skilled workers is not likely to significantly increase business ownership rates. There is one exception to this, we do find a positive association between wealth and self-employment entry among native 
born women. It is hence possible that increasing the availability of start-up capital for these lowskilled women would increase their business ownership rates. It is also possible that better funded women owned business would lead to better performance, an issue not directly addressed in this research.

Although the findings do not provide strong support for policy intervention that directly encourages business ownership among low-skilled workers, it is important to point out that several potentially important benefits of low-skilled self-employment have not been addressed. Our analyses have not examined other possible measures of success, including wealth accumulation. Our data do suggest that business owners' mean and median household net worth are higher than those of wage/salary workers. Given that our data only include wealth information at the household level, we cannot reliably ascertain that this relationship is a consequence of the individual's self-employment performance, and not due to, for example spousal economic activity. Wealth accumulation too is an important topic for future research. Additionally and importantly, the research has not analyzed whether low-skilled selfemployment leads to greater job creation. This is a topic that the data utilized here are not well suited to address but given potential implications, it is an important issue for future research to address.

Lastly, given the lack of strong evidence in favor of additional self-employment assistance among low-skilled workers, what are alternative policies which can provide upward mobility for this economically vulnerable part of the workforce? No simple solution exists but it is likely that efforts aimed at increasing skills and educational attainment are the ones most likely to lead to lasting improved economic outcomes among the current population with low schooling levels. However, few adult workers who did not complete high school are likely to return to school to complete their secondary education. Similarly, enticing adult high school graduates, who have not been in school for years, to enroll in college level classes to obtain higher levels of educations is also likely to prove challenging. This point to the importance of ensuring that current and future students are provided with ample opportunities to not only complete secondary education, but to also obtain skills at the post-secondary level. 


\section{References}

Bates, Timothy. 1989. "The Changing Nature of Minority Business: A Comparative Analysis of Asian, Nonminority, and Black-Owned Businesses" The Review of Black Political Economy, 18, Fall: 25-42.

Bates, Timothy. 1990. "Entrepreneur Human Capital Inputs and Small Business Longevity," Review of Economics and Statistics 72 (4): 551-59.

Bates, Timothy. 1993. Assessment of State and Local Government Minority Business Development Programs. Report to the U.S. Department of Commerce Minority Business Development Agency. Washington, D.C.: U.S. Department of Commerce.

Bates, Timothy. 1997. Race, Self-Employment \& Upward Mobility: An Illusive American Dream, Washington, D.C.: Woodrow Wilson Center Press and Baltimore: John Hopkins University Press.

Baumgartner, Hans J. and Marco Caliendo, 2008. “Turning Unemployment into SelfEmployment: Effectiveness and Efficiency of Two Start-Up Programs,” Oxford Bulletin of Economics and Statistics, 70(3), pp. 347-373.

Blanchflower, David G. 2004. “Self-Employment: More May Not Be Better”, NBER Working paper No. 10286.

Blanchflower, David G., P. Levine and D. Zimmerman. 2003. "Discrimination in the Small Business Credit Market", Review of Economics and Statistics, November, 85(4): 930-943

Blanchflower, David G. and Andrew J. Oswald. 1998. “What Makes an Entrepreneur?” Journal of Labor Economics,16, 26-60.

Borjas, George J. 2003. “The Labor Demand Curve is Downward Sloping: Reexamining the Impact of Immigration on the Labor Market," Quarterly Journal of Economics, November, pp. 1335-1374.

Brock, William A., and Evans, David S. 1986. The Economics of Small Businesses: Their Role and Regulation in the U.S. Economy. New York: Holmes and Meier.

Brush, C., Carter, N., Gatewood, E., Greene, P., \& Hart, M. 2004. Clearing the Hurdles: Women Building High-Growth Businesses. Upper Saddle River, NJ: Pearson Education Inc.

Caliendo, Marco, 2009. “Start-Up Subsidies in East Germany: Finally, a Policy that Works?” IZA Discussion Paper No. 3360, February.

Cavalluzzo, Ken, Linda Cavalluzzo, and John Wolken. 2002. "Competition, Small Business Financing, and Discrimination: Evidence from a New Survey,” Journal of Business, 25(4). 
Dunn, T. and D. Holtz-Eakin. 2000. "Financial Capital, Human Capital, and the Transition to Self-Employment: Evidence from Intergenerational Links.” Journal of Labor Economics,18, 282-305.

Evans, David S. and Boyan Jovanovic. 1989. “An Estimated Model of Entrepreneurial Choice under Liquidity Constraints.” Journal of Political Economy, 97, 808-827.

Evans, David S. and Linda S. Leighton. 1989. “Some Empirical Aspects of Entrepreneurship”. American Economic Review, 79, 519-35.

Fairlie, Robert W. and Alicia Robb. 2008. Race and Entrepreneurial Success: Black-, Asian-, and White-Owned Businesses in the United States, MIT Press.

Fairlie, Robert W. 2006 "Entrepreneurship among Disadvantaged Groups: An Analysis of the Dynamics of Self-Employment by Gender, Race and Education," Handbook of Entrepreneurship, Vol 2, eds. Simon C. Parker, Zoltan J. Acs, and David R. Audretsch, Kluwer Academic Publishers.

Fairlie, Robert W. 2005 “Entrepreneurship and Earnings among Young Adults from Disadvantaged Families” Small Business Economics, 25(3): 223-236.

Fairlie, Robert W. 2004 “Earnings Growth among Less-Educated Business Owners” Industrial Relations, 43 (3):634-659.

Fairlie, Robert W. 1999. "The Absence of the African-American Owned Business: An Analysis of the Dynamics of Self-Employment." Journal of Labor Economics, 17(1): 80-108.

Fairlie, Robert W. and Bruce D. Meyer (2003) ، “The Effect of Immigration on Native SelfEmployment” Journal of Labor Economics, vol. 21, no. 3, pp 619-50.

Hamilton, Barton H. 2000. "Does Entrepreneurship Pay? An Empirical Analysis of the Returns of Self-Employment” The Journal of Political Economy, Vol. 108, No. 3, pp. 604-631

Holtz-Eakin, Douglas, David Joulfaian and Harvey S. Rosen. 1994a. "Sticking it Out: Entrepreneurial Survival and Liquidity Constraints.” Journal of Political Economy, 102, 53-75.

Holtz-Eakin, Douglas, David Joulfaian and Harvey S. Rosen. 1994b. “Entrepreneurial Decisions and Liquidity Constraints” Rand Journal of Economics, 25, 334-47.

Hurst, Erik, and Annamaria Lusardi. 2004. "Liquidity Constraints, Household Wealth, and Entrepreneurship," Journal of Political Economy, 112(2): 319-347.

Hout, Michael and Harvey Rosen. 2000. "Self-Employment, Family Background, and Race,” Journal of Human Resources, 35(4), 670-692. 
Kihlstrom, Richard E. and Jean-Jacques Laffont. 1979. “A General Equilibrium Entrepreneurial Theory of Firm Formation Based on Risk Aversion” Journal of Political Economy, 87:4, 719748.

Light, I., 1972. Ethnic Enterprise in North America: Business and Welfare among Chinese, Japanese, and Blacks. University of California Press, Berkeley and Los Angeles, CA.

Lindh, Thomas and Henry Ohlsson. 1996. "Self-Employment and Windfall Gains. Evidence from the Swedish Lottery”. The Economic Journal, 106, 1515-1526.

Lofstrom, Magnus and Chunbei Wang. Forthcoming. "Mexican-American Self-Employment: A Dynamic Analysis of Business Ownership”, Research in Labor Economics.

Lofstrom, Magnus and Timothy Bates. Forthcoming. "Latina Entrepreneurs”, Small Business Economics.

Neumark, David, Brandon Wall and Junfu Zhang (2008) “Do Small Businesses Create More Jobs? New Evidence for the United States from the National Establishment Time Series” IZA Discussion Paper 3888, December.

Parker, Simon C. 2004. The Economics of Self-employment and Entrepreneurship, Cambridge University Press, Cambridge.

Raphael, Steven. 2008. "Boosting the Earnings and Employment of Low-Skilled Workers in the United States: Making Work Pay and Removing Barriers to Employment and Social Mobility” in Bartik, Timothy and Susan N. Houseman (eds) A Future of Good Jobs? America's Challenge in the Global Economy pp. 245-304.

Rees, Hedley, and Shah, Anup. 1986. "An Empirical Analysis of Self-Employment in the U.K." Journal of Applied Econometrics, 1:95-108. 
Tables

Table 1

Number of Self Employed Individuals in the U.S., 1980 to 2007, by Skill Group.

\begin{tabular}{|c|c|c|c|c|c|c|c|c|}
\hline Year & $\begin{array}{l}\text { High School } \\
\text { or Less }\end{array}$ & $\begin{array}{l}\text { Some } \\
\text { College }\end{array}$ & $\begin{array}{l}\text { College } \\
\text { Graduate }\end{array}$ & All & $\begin{array}{c}\text { High School } \\
\text { or Less }\end{array}$ & $\begin{array}{l}\text { Some } \\
\text { College }\end{array}$ & $\begin{array}{l}\text { College } \\
\text { Graduate }\end{array}$ & All \\
\hline & \multicolumn{8}{|c|}{ U.S. Born } \\
\hline & \multicolumn{4}{|c|}{ Men } & \multicolumn{4}{|c|}{ Women } \\
\hline 1980 & $4,059,900$ & $1,248,500$ & $1,752,300$ & $7,060,700$ & $1,346,720$ & 467,920 & 373,980 & $2,188,620$ \\
\hline 1990 & $3,443,392$ & $2,037,443$ & $2,247,791$ & $7,728,626$ & $1,711,725$ & $1,221,160$ & 879,587 & $3,812,472$ \\
\hline 2000 & $3,382,087$ & $2,331,583$ & $2,574,546$ & $8,288,216$ & $1,681,781$ & $1,535,579$ & $1,282,279$ & 4,499,639 \\
\hline 2005 & 3,559,399 & $2,578,303$ & $3,012,577$ & $9,150,279$ & $1,720,593$ & $1,690,777$ & $1,650,717$ & $5,062,087$ \\
\hline 2006 & $3,683,961$ & $2,544,878$ & $3,000,674$ & $9,229,513$ & $1,693,497$ & $1,706,371$ & $1,709,890$ & $5,109,758$ \\
\hline 2007 & $3,636,241$ & $2,548,555$ & $3,013,403$ & $9,198,199$ & $1,683,663$ & $1,692,124$ & $1,734,436$ & $5,110,223$ \\
\hline \multicolumn{9}{|l|}{ Period } \\
\hline Change & $-423,659$ & $1,300,055$ & $1,261,103$ & $2,137,499$ & 336,943 & $1,224,204$ & $1,360,456$ & $2,921,603$ \\
\hline
\end{tabular}

\section{Foreign Born}

\begin{tabular}{|c|c|c|c|c|c|c|c|c|}
\hline \multirow[b]{2}{*}{1980} & \multicolumn{4}{|c|}{ Men } & \multicolumn{4}{|c|}{ Women } \\
\hline & 277,160 & 73,260 & 139,160 & 489,580 & 102,700 & 32,580 & 33,820 & 169,100 \\
\hline 1990 & 400,782 & 175,984 & 252,590 & 829,356 & 231,302 & 101,856 & 97,763 & 430,921 \\
\hline 2000 & 651,069 & 252,403 & 377,102 & $1,280,574$ & 411,347 & 167,993 & 187,230 & 766,570 \\
\hline 2005 & 837,368 & 341,776 & 534,838 & $1,713,982$ & 546,335 & 225,259 & 301,712 & $1,073,306$ \\
\hline 2006 & 914,416 & 342,237 & 545,850 & $1,802,503$ & 586,858 & 236,005 & 308,357 & $1,131,220$ \\
\hline 2007 & 944,585 & 352,100 & 561,402 & $1,858,087$ & 603,127 & 222,939 & 321,871 & $1,147,937$ \\
\hline \multicolumn{9}{|l|}{ Period } \\
\hline Change & 667,425 & 278,840 & 422,242 & $1,368,507$ & 500,427 & 190,359 & 288,051 & 978,837 \\
\hline
\end{tabular}

Source: 1980, 1990 and 2000 U.S. Census; 2005-2007 American Community Survey. 
Table 2.

U.S. Self-Employment Rates, 1980 to 2007, by Skill Group.

\begin{tabular}{|c|c|c|c|c|c|c|}
\hline Year & $\begin{array}{c}\text { High School } \\
\text { or Less }\end{array}$ & $\begin{array}{l}\text { Some } \\
\text { College }\end{array}$ & $\begin{array}{l}\text { College } \\
\text { Graduate }\end{array}$ & $\begin{array}{c}\text { High School } \\
\text { or Less }\end{array}$ & $\begin{array}{l}\text { Some } \\
\text { College }\end{array}$ & $\begin{array}{c}\text { College } \\
\text { Graduate }\end{array}$ \\
\hline & \multicolumn{6}{|c|}{ U.S. Born } \\
\hline & \multicolumn{3}{|c|}{ Men } & \multicolumn{3}{|c|}{ Women } \\
\hline 1980 & $10.1 \%$ & $11.0 \%$ & $15.2 \%$ & $3.9 \%$ & $4.5 \%$ & $5.0 \%$ \\
\hline 1990 & $10.2 \%$ & $10.6 \%$ & $14.7 \%$ & $5.7 \%$ & $6.1 \%$ & $7.1 \%$ \\
\hline 2000 & $10.4 \%$ & $10.6 \%$ & $14.3 \%$ & $6.0 \%$ & $6.3 \%$ & $7.4 \%$ \\
\hline 2005 & $11.2 \%$ & $11.5 \%$ & $15.2 \%$ & $6.1 \%$ & $6.8 \%$ & $8.2 \%$ \\
\hline 2006 & $11.0 \%$ & $11.2 \%$ & $14.9 \%$ & $6.0 \%$ & $6.6 \%$ & $8.3 \%$ \\
\hline \multirow[t]{3}{*}{2007} & $11.0 \%$ & $11.0 \%$ & $14.6 \%$ & $6.1 \%$ & $6.5 \%$ & $8.1 \%$ \\
\hline & \multicolumn{6}{|c|}{ Foreign Born } \\
\hline & & Men & & & Women & \\
\hline 1980 & $9.8 \%$ & $10.6 \%$ & $14.9 \%$ & $4.2 \%$ & $5.1 \%$ & $6.3 \%$ \\
\hline 1990 & $9.5 \%$ & $12.2 \%$ & $15.1 \%$ & $7.0 \%$ & $7.3 \%$ & $8.4 \%$ \\
\hline 2000 & $9.1 \%$ & $11.5 \%$ & $12.8 \%$ & $8.4 \%$ & $7.6 \%$ & $7.9 \%$ \\
\hline 2005 & $10.0 \%$ & $13.4 \%$ & $14.2 \%$ & $9.9 \%$ & $8.7 \%$ & $9.3 \%$ \\
\hline 2006 & $10.3 \%$ & $13.0 \%$ & $13.7 \%$ & $10.4 \%$ & $8.9 \%$ & $9.2 \%$ \\
\hline 2007 & $10.5 \%$ & $13.5 \%$ & $13.8 \%$ & $10.6 \%$ & $8.4 \%$ & $9.4 \%$ \\
\hline
\end{tabular}

Source: 1980, 1990 and 2000 U.S. Census; 2005-2007 American Community Survey. 
Table 3

Summary Statistics, Total Annual Earnings Measures, Low-Skilled Men

\begin{tabular}{lcccccc}
\hline & \multicolumn{5}{c}{ Percentile } \\
& Mean & 10 & 25 & Median & 75 & 90 \\
\cline { 2 - 7 } & \multicolumn{6}{c}{ U.S. Born } \\
Self-Employment & 38,177 & 6,537 & 14,083 & 27,475 & 46,028 & 76,640 \\
Wage/Salary & 32,825 & 9,768 & 18,175 & 28,941 & 42,524 & 58,127 \\
Difference (\$) & 5,352 & $-3,231$ & $-4,092$ & $-1,466$ & 3,504 & 18,514 \\
Difference (\%) & $16.3 \%$ & $-33.1 \%$ & $-22.5 \%$ & $-5.1 \%$ & $8.2 \%$ & $31.9 \%$ \\
& \multicolumn{7}{c}{ Total Annual Earnings \& Capital Income } \\
Self-Employment & 38,768 & 6,781 & 14,527 & 27,948 & 46,702 & 79,358 \\
Wage/Salary & 33,028 & 9,850 & 18,244 & 29,060 & 42,756 & 58,551 \\
Difference (\$) & 5,740 & $-3,069$ & $-3,717$ & $-1,112$ & 3,946 & 20,807 \\
Difference (\%) & $17.4 \%$ & $-31.2 \%$ & $-20.4 \%$ & $-3.8 \%$ & $9.2 \%$ & $35.5 \%$
\end{tabular}

Total Annual Earnings, Business Equity Adjusted

$\begin{array}{lcccccc}\text { Self-Employment } & 33,252 & 3,364 & 11,244 & 23,949 & 42,612 & 70,846 \\ \text { Wage/Salary } & 32,825 & 9,768 & 18,175 & 28,941 & 42,524 & 58,127 \\ \text { Difference (\$) } & 427 & -6,403 & -6,930 & -4,993 & 88 & 12,719 \\ \text { Difference (\%) } & 1.3 \% & -65.6 \% & -38.1 \% & -17.3 \% & 0.2 \% & 21.9 \%\end{array}$

Foreign Born

\begin{tabular}{lcccccc} 
& \multicolumn{7}{c}{ Total Annual Earnings } \\
Self-Employment & 33,451 & 5,655 & 11,785 & 22,352 & 38,669 & 70,055 \\
Wage/Salary & 26,452 & 10,292 & 16,174 & 23,163 & 32,416 & 46,038 \\
$\quad$ Difference (\$) & 6,999 & $-4,637$ & $-4,389$ & -811 & 6,253 & 24,017 \\
Difference (\%) & $26.5 \%$ & $-45.1 \%$ & $-27.1 \%$ & $-3.5 \%$ & $19.3 \%$ & $52.2 \%$
\end{tabular}

\begin{tabular}{lcccccc} 
& \multicolumn{7}{c}{ Total Annual Earnings \& Capital Income } \\
Self-Employment & 33,719 & 5,839 & 12,014 & 22,568 & 38,898 & 70,208 \\
Wage/Salary & 26,548 & 10,325 & 16,194 & 23,208 & 32,508 & 46,191 \\
$\quad$ Difference (\$) & 7,172 & $-4,486$ & $-4,180$ & -640 & 6,389 & 24,017 \\
Difference (\%) & $27.0 \%$ & $-43.4 \%$ & $-25.8 \%$ & $-2.8 \%$ & $19.7 \%$ & $52.0 \%$
\end{tabular}

Total Annual Earnings, Business Equity Adjusted

\begin{tabular}{lcccccc} 
Self-Employment & 30,010 & 3,949 & 10,823 & 20,568 & 36,949 & 63,932 \\
Wage/Salary & 26,452 & 10,292 & 16,174 & 23,163 & 32,416 & 46,038 \\
Difference (\$) & 3,558 & $-6,343$ & $-5,351$ & $-2,596$ & 4,533 & 17,894 \\
Difference (\%) & $13.4 \%$ & $-61.6 \%$ & $-33.1 \%$ & $-11.2 \%$ & $14.0 \%$ & $38.9 \%$ \\
\hline
\end{tabular}

Source: 1996, 2001 and 2004 Panels of the Survey of Income and Program Participation (SIPP). 


\section{Table 4}

Summary Statistics, Total Annual Earnings Measures, Low-Skilled Women

\begin{tabular}{lcccccc}
\hline & \multicolumn{7}{c}{ Percentile } \\
& Mean & 10 & 25 & Median & 75 & 90 \\
\cline { 2 - 7 } & \multicolumn{6}{c}{ U.S. Born } \\
Self-Employment & 21,092 & 2,897 & 6,574 & 13,824 & 26,146 & 45,298 \\
Wage/Salary & 22,287 & 6,098 & 11,577 & 19,492 & 29,203 & 40,212 \\
Difference (\$) & $-1,195$ & $-3,201$ & $-5,003$ & $-5,668$ & $-3,057$ & 5,086 \\
Difference (\%) & $-5.4 \%$ & $-52.5 \%$ & $-43.2 \%$ & $-29.1 \%$ & $-10.5 \%$ & $12.6 \%$ \\
& \multicolumn{7}{c}{ (\%otal Annual Earnings \& Capital Income } \\
Self-Employment & 21,764 & 3,035 & 7,024 & 14,475 & 26,997 & 46,889 \\
Wage/Salary & 22,509 & 6,217 & 11,677 & 19,678 & 29,530 & 40,552 \\
Difference (\$) & -745 & $-3,183$ & $-4,653$ & $-5,203$ & $-2,533$ & 6,337 \\
Difference (\%) & $-3.3 \%$ & $-51.2 \%$ & $-39.8 \%$ & $-26.4 \%$ & $-8.6 \%$ & $15.6 \%$
\end{tabular}

Total Annual Earnings, Business Equity Adjusted

$\begin{array}{lllllll}\text { Self-Employment } & 17,437 & 1,264 & 4,925 & 11,961 & 22,735 & 39,535 \\ \text { Wage/Salary } & 22,287 & 6,098 & 11,577 & 19,492 & 29,203 & 40,212 \\ \text { Difference (\$) } & -4,850 & -4,834 & -6,653 & -7,531 & -6,468 & -677 \\ \text { Difference (\%) } & -21.8 \% & -79.3 \% & -57.5 \% & -38.6 \% & -22.1 \% & -1.7 \%\end{array}$

Foreign Born

\begin{tabular}{lcccccc} 
& \multicolumn{7}{c}{ Total Annual Earnings } \\
Self-Employment & 21,400 & 3,226 & 6,912 & 13,584 & 23,734 & 41,136 \\
Wage/Salary & 19,189 & 5,640 & 10,362 & 16,477 & 24,464 & 35,045 \\
$\quad$ Difference (\$) & 2,211 & $-2,414$ & $-3,450$ & $-2,892$ & -730 & 6,091 \\
Difference (\%) & $11.5 \%$ & $-42.8 \%$ & $-33.3 \%$ & $-17.6 \%$ & $-3.0 \%$ & $17.4 \%$
\end{tabular}

$\begin{array}{lcccccc}\text { Self-Employment } & 21,638 & 3,435 & 7,032 & 13,728 & 23,813 & 41,699 \\ \text { Wage/Salary } & 19,343 & 5,722 & 10,384 & 16,555 & 24,641 & 35,528 \\ \text { Difference (\$) } & 2,295 & -2,287 & -3,352 & -2,827 & -828 & 6,171 \\ \text { Difference (\%) } & 11.9 \% & -40.0 \% & -32.3 \% & -17.1 \% & -3.4 \% & 17.4 \%\end{array}$

Total Annual Earnings, Business Equity Adjusted

\begin{tabular}{lcccccc} 
Self-Employment & 20,579 & 2,524 & 5,948 & 12,879 & 22,653 & 40,052 \\
Wage/Salary & 19,189 & 5,640 & 10,362 & 16,477 & 24,464 & 35,045 \\
Difference (\$) & 1,390 & $-3,115$ & $-4,414$ & $-3,598$ & $-1,812$ & 5,007 \\
Difference (\%) & $7.2 \%$ & $-55.2 \%$ & $-42.6 \%$ & $-21.8 \%$ & $-7.4 \%$ & $14.3 \%$ \\
\hline
\end{tabular}

Source: 1996, 2001 and 2004 Panels of the Survey of Income and Program Participation (SIPP). 


\section{Table 5}

Descriptive Statistics, Low-Skilled Men

\begin{tabular}{|c|c|c|c|c|}
\hline \multirow[b]{3}{*}{ Variable } & \multicolumn{2}{|c|}{ U.S. Born } & \multicolumn{2}{|c|}{ Foreign Born } \\
\hline & Self- & Wage/ & Self- & Wage/ \\
\hline & & & & Salary \\
\hline Years of Schooling & 11.51 & 11.58 & 10.32 & 10.05 \\
\hline Less than High School & $17.0 \%$ & $16.0 \%$ & $32.1 \%$ & $38.7 \%$ \\
\hline High School Graduate & $83.0 \%$ & $84.0 \%$ & $67.9 \%$ & $61.3 \%$ \\
\hline Age & 44.04 & 38.17 & 42.54 & 36.68 \\
\hline Youngest Child Younger Than 1 & $11.3 \%$ & $10.8 \%$ & $17.3 \%$ & $18.5 \%$ \\
\hline Youngest Child Aged 1 & $3.0 \%$ & $3.1 \%$ & $5.8 \%$ & $5.4 \%$ \\
\hline Youngest Child Between Ages 2 and 3 & $4.4 \%$ & $5.1 \%$ & $7.8 \%$ & $7.6 \%$ \\
\hline Youngest Child Between Ages 4 and 5 & $4.3 \%$ & $4.0 \%$ & $6.9 \%$ & $5.9 \%$ \\
\hline Youngest Child Between Ages 6 and 12 & $15.2 \%$ & $14.6 \%$ & $13.4 \%$ & $15.6 \%$ \\
\hline Youngest Child Teenager & $5.5 \%$ & $6.1 \%$ & $4.8 \%$ & $4.6 \%$ \\
\hline Single & $31.0 \%$ & $46.5 \%$ & $28.7 \%$ & $43.8 \%$ \\
\hline Persons in Household & 3.18 & 3.23 & 3.95 & 4.04 \\
\hline Metropolitan Resident & $64.1 \%$ & $72.0 \%$ & $83.4 \%$ & $86.1 \%$ \\
\hline White & $87.1 \%$ & $74.8 \%$ & $34.9 \%$ & $26.0 \%$ \\
\hline Hispanic & $5.5 \%$ & $10.4 \%$ & $48.8 \%$ & $59.6 \%$ \\
\hline African-American & $5.6 \%$ & $12.7 \%$ & $4.3 \%$ & $6.7 \%$ \\
\hline Asian & $0.6 \%$ & $0.4 \%$ & $8.6 \%$ & $5.2 \%$ \\
\hline Other Ethnic Group & $1.2 \%$ & $1.7 \%$ & $3.5 \%$ & $2.5 \%$ \\
\hline Years Since Migration & & & 19.2 & 16.4 \\
\hline Not Naturalized Citizen & & & $44.4 \%$ & $51.0 \%$ \\
\hline Years at Job & 11.02 & 7.75 & 7.64 & 5.43 \\
\hline Typical Weekly Hours Worked & 50.37 & 43.5 & 48.43 & 42.83 \\
\hline \multicolumn{5}{|l|}{ Previous Year's Labor Force Status } \\
\hline Wage/Salary & $9.1 \%$ & $87.6 \%$ & $14.5 \%$ & $87.5 \%$ \\
\hline Self-Employed & $83.3 \%$ & $1.3 \%$ & $76.0 \%$ & $1.3 \%$ \\
\hline Wage/Salary, Less than 15 Hours/Week & $0.1 \%$ & $0.8 \%$ & & $0.5 \%$ \\
\hline Self-Employed, Less than 15 Hours/Week & $3.3 \%$ & $0.3 \%$ & $1.9 \%$ & $0.2 \%$ \\
\hline Unemployed & $1.2 \%$ & $3.7 \%$ & $1.6 \%$ & $3.8 \%$ \\
\hline Welfare & $0.5 \%$ & $1.1 \%$ & $0.7 \%$ & $1.3 \%$ \\
\hline Not in the Labor Force & $2.6 \%$ & $5.2 \%$ & $5.3 \%$ & $5.3 \%$ \\
\hline Number of Observations & 4,466 & 29,394 & 1,198 & 9,063 \\
\hline
\end{tabular}

Source: 1996, 2001 and 2004 Panels of the Survey of Income and Program Participation (SIPP). 


\section{Table 6}

Descriptive Statistics, Low-Skilled Women

\begin{tabular}{|c|c|c|c|c|}
\hline \multirow[b]{3}{*}{ Variable } & \multicolumn{2}{|c|}{ U.S. Born } & \multicolumn{2}{|c|}{ Foreign Born } \\
\hline & Self- & Wage/ & Self- & Wage/ \\
\hline & Employed & Salary & Employed & Salary \\
\hline Years of Schooling & 11.59 & 11.69 & 10.09 & 10.4 \\
\hline Less than High School & $15.3 \%$ & $13.3 \%$ & $33.6 \%$ & $32.4 \%$ \\
\hline High School Graduate & $84.7 \%$ & $86.7 \%$ & $66.4 \%$ & $67.6 \%$ \\
\hline Age & 44.77 & 40.1 & 43.45 & 39.32 \\
\hline Youngest Child Younger Than 1 & $10.9 \%$ & $10.1 \%$ & $10.4 \%$ & $13.7 \%$ \\
\hline Youngest Child Aged 1 & $3.3 \%$ & $3.8 \%$ & $5.0 \%$ & $5.6 \%$ \\
\hline Youngest Child Between Ages 2 and 3 & $4.6 \%$ & $5.8 \%$ & $9.3 \%$ & $7.4 \%$ \\
\hline Youngest Child Between Ages 4 and 5 & $4.7 \%$ & $5.2 \%$ & $6.8 \%$ & $7.0 \%$ \\
\hline Youngest Child Between Ages 6 and 12 & $18.2 \%$ & $17.3 \%$ & $19.0 \%$ & $21.0 \%$ \\
\hline Youngest Child Teenager & $6.4 \%$ & $6.6 \%$ & $7.4 \%$ & $5.8 \%$ \\
\hline Single & $28.6 \%$ & $47.9 \%$ & $36.6 \%$ & $45.1 \%$ \\
\hline Persons in Household & 3.15 & 3.17 & 3.83 & 3.88 \\
\hline Metropolitan Resident & $70.3 \%$ & $73.9 \%$ & $93.0 \%$ & $87.2 \%$ \\
\hline White & $83.9 \%$ & $73.1 \%$ & $27.0 \%$ & $28.9 \%$ \\
\hline Hispanic & $6.0 \%$ & $8.8 \%$ & $49.1 \%$ & $48.6 \%$ \\
\hline African-American & $7.7 \%$ & $15.7 \%$ & $6.1 \%$ & $9.6 \%$ \\
\hline Asian & $0.3 \%$ & $0.4 \%$ & $14.1 \%$ & $9.5 \%$ \\
\hline Other Ethnic Group & $2.1 \%$ & $1.9 \%$ & $3.7 \%$ & $3.5 \%$ \\
\hline Years Since Migration & & & 18.9 & 17.9 \\
\hline Not Naturalized Citizen & & & $49.2 \%$ & $45.4 \%$ \\
\hline Years at Job & 8.06 & 6.85 & 6.49 & 4.89 \\
\hline Typical Weekly Hours Worked & 43.08 & 38.49 & 41.1 & 38.58 \\
\hline \multicolumn{5}{|l|}{ Previous Year's Labor Force Status } \\
\hline Wage/Salary & $9.9 \%$ & $85.1 \%$ & $9.3 \%$ & $80.0 \%$ \\
\hline Self-Employed & $74.3 \%$ & $0.7 \%$ & $73.7 \%$ & $0.9 \%$ \\
\hline Wage/Salary, Less than 15 Hours/Week & $0.5 \%$ & $1.6 \%$ & $0.3 \%$ & $1.6 \%$ \\
\hline Self-Employed, Less than 15 Hours/Week & $5.6 \%$ & $0.3 \%$ & $2.8 \%$ & $0.2 \%$ \\
\hline Unemployed & $1.8 \%$ & $3.0 \%$ & $2.3 \%$ & $3.9 \%$ \\
\hline Welfare & $1.4 \%$ & $2.8 \%$ & $2.2 \%$ & $3.3 \%$ \\
\hline Not in the Labor Force & $6.5 \%$ & $6.5 \%$ & $9.4 \%$ & $10.2 \%$ \\
\hline Number of Observations & 1,922 & 26,818 & 589 & 6,368 \\
\hline
\end{tabular}


Table 7

Ordinary Least Squares, Log of Total Annual Earnings, Men.

\begin{tabular}{|c|c|c|c|c|}
\hline & \multicolumn{2}{|c|}{ Native } & \multicolumn{2}{|c|}{ Immigrant } \\
\hline & $\begin{array}{c}\text { Self } \\
\text { Employed }\end{array}$ & Wage/Salary & $\begin{array}{c}\text { Self } \\
\text { Employed }\end{array}$ & Wage/Salary \\
\hline High School Graduate & $\begin{array}{c}0.1701^{\star \star} \\
(3.93)\end{array}$ & $\begin{array}{c}0.22079^{* *} \\
(19.35)\end{array}$ & $\begin{array}{c}0.05399 \\
(0.72)\end{array}$ & $\begin{array}{c}0.16234^{* *} \\
(10.49)\end{array}$ \\
\hline Age & $\begin{array}{c}0.11957^{\star *} \\
(2.1)\end{array}$ & $\begin{array}{c}0.16288^{\star \star} \\
(14.75)\end{array}$ & $\begin{array}{c}0.20779^{*} \\
(1.95)\end{array}$ & $\begin{array}{c}0.23005^{\star \star} \\
(11.9)\end{array}$ \\
\hline Age Squared/100 & $\begin{array}{c}-0.24282^{*} \\
(-1.8)\end{array}$ & $\begin{array}{c}-0.31811^{\star *} \\
(-11.33)\end{array}$ & $\begin{array}{c}-0.44793^{*} \\
(-1.73)\end{array}$ & $\begin{array}{c}-0.50023^{\star \star} \\
(-10.1)\end{array}$ \\
\hline Age Cubed/1000 & $\begin{array}{c}0.01507 \\
(1.47)\end{array}$ & $\begin{array}{c}0.01916^{* *} \\
(8.49)\end{array}$ & $\begin{array}{c}0.03028 \\
(1.51)\end{array}$ & $\begin{array}{c}0.03444^{\star *} \\
(8.57)\end{array}$ \\
\hline Youngest Child Younger Than 1 & $\begin{array}{c}0.02499 \\
(0.34)\end{array}$ & $\begin{array}{c}0.04028^{\star *} \\
(2.36)\end{array}$ & $\begin{array}{l}0.1501 \\
(1.05)\end{array}$ & $\begin{array}{c}-0.04292 \\
(-1.52)\end{array}$ \\
\hline Youngest Child Aged 1 & $\begin{array}{c}0.11628 \\
(1.3)\end{array}$ & $\begin{array}{c}0.04794^{*} \\
(1.95)\end{array}$ & $\begin{array}{c}0.19878 \\
(1.15)\end{array}$ & $\begin{array}{c}-0.08225^{\star *} \\
(-2.11)\end{array}$ \\
\hline Youngest Child Between Ages 2 and 3 & $\begin{array}{c}-0.03241 \\
(-0.32)\end{array}$ & $\begin{array}{c}0.04684^{\star *} \\
(2.47)\end{array}$ & $\begin{array}{c}0.2061 \\
(1.47)\end{array}$ & $\begin{array}{c}-0.08504^{\star *} \\
(-2.73)\end{array}$ \\
\hline Youngest Child Between Ages 4 and 5 & $\begin{array}{c}0.06059 \\
(0.77)\end{array}$ & $\begin{array}{c}0.02963 \\
(1.4)\end{array}$ & $\begin{array}{c}0.29398^{\star *} \\
(2.04)\end{array}$ & $\begin{array}{c}-0.07617^{\star *} \\
(-2.29)\end{array}$ \\
\hline Youngest Child Between Ages 6 and 12 & $\begin{array}{c}-0.09613 \\
(-1.6)\end{array}$ & $\begin{array}{c}-0.00109 \\
(-0.07)\end{array}$ & $\begin{array}{c}0.36796^{* *} \\
(3.2)\end{array}$ & $\begin{array}{c}-0.05823^{* *} \\
(-2.15)\end{array}$ \\
\hline Youngest Child Teenager & $\begin{array}{c}-0.03818 \\
(-0.51)\end{array}$ & $\begin{array}{c}0.03025 \\
(1.46)\end{array}$ & $\begin{array}{c}0.20479 \\
(1.19)\end{array}$ & $\begin{array}{l}-0.018 \\
(-0.45)\end{array}$ \\
\hline Single & $\begin{array}{c}-0.1572^{\star *} \\
(-2.81)\end{array}$ & $\begin{array}{c}-0.18973^{\star *} \\
(-15.76)\end{array}$ & $\begin{array}{c}0.00604 \\
(0.05)\end{array}$ & $\begin{array}{c}-0.12752^{\star \star} \\
(-5.3)\end{array}$ \\
\hline Single*Youngest Child Younger Than 1 & $\begin{array}{c}-0.36706^{\star \star} \\
(-2.26)\end{array}$ & $\begin{array}{c}0.08103^{* \star} \\
(2.51)\end{array}$ & $\begin{array}{c}0.51319^{\star *} \\
(2.62)\end{array}$ & $\begin{array}{l}-0.001 \\
(-0.02)\end{array}$ \\
\hline Single*Youngest Child Aged 1 & $\begin{array}{c}-0.33362 \\
(-1.26)\end{array}$ & $\begin{array}{c}-0.01186 \\
(-0.19)\end{array}$ & $\begin{array}{c}-0.25871 \\
(-0.62)\end{array}$ & $\begin{array}{c}0.06073 \\
(0.91)\end{array}$ \\
\hline Single*Youngest Child Between Ages 2 and 3 & $\begin{array}{c}0.02295 \\
(0.12)\end{array}$ & $\begin{array}{c}0.01552 \\
(0.37)\end{array}$ & $\begin{array}{c}-0.34978 \\
(-0.86)\end{array}$ & $\begin{array}{c}-0.07171 \\
(-0.94)\end{array}$ \\
\hline Single*Youngest Child Between Ages 4 and 5 & $\begin{array}{c}0.4694^{\star *} \\
(2.09)\end{array}$ & $\begin{array}{c}0.01988 \\
(0.4)\end{array}$ & $\begin{array}{c}0.24795 \\
(0.56)\end{array}$ & $\begin{array}{c}0.09646 \\
(1.42)\end{array}$ \\
\hline Single*Youngest Child Between Ages 6 \& 12 & $\begin{array}{c}0.08339 \\
(0.57)\end{array}$ & $\begin{array}{c}-0.0279 \\
(-1.05)\end{array}$ & $\begin{array}{c}-0.35353 \\
(-1.53)\end{array}$ & $\begin{array}{c}0.05337 \\
(1.25)\end{array}$ \\
\hline Single*Youngest Child Teenager & $\begin{array}{c}-0.51284^{*} \\
(-1.8)\end{array}$ & $\begin{array}{l}-0.039 \\
(-1.2)\end{array}$ & $\begin{array}{c}-0.6462^{* *} \\
(-2.03)\end{array}$ & $\begin{array}{c}-0.03651 \\
(-0.55)\end{array}$ \\
\hline Persons in Household & $\begin{array}{c}0.0291^{* *} \\
(2.12)\end{array}$ & $\begin{array}{c}-0.01145^{\star *} \\
(-2.92)\end{array}$ & $\begin{array}{c}-0.03955^{*} \\
(-1.72)\end{array}$ & $\begin{array}{c}-0.00514 \\
(-1.15)\end{array}$ \\
\hline Metropolitan Resident & $\begin{array}{c}0.19498^{\star *} \\
(5.14)\end{array}$ & $\begin{array}{c}0.12125^{\star *} \\
(12.72)\end{array}$ & $\begin{array}{c}0.29309^{\star *} \\
(2.91)\end{array}$ & $\begin{array}{c}0.05817^{\star \star} \\
(2.46)\end{array}$ \\
\hline Hispanic & $\begin{array}{c}-0.10979 \\
(-1.54)\end{array}$ & $\begin{array}{c}-0.11441^{\star *} \\
(-6.67)\end{array}$ & $\begin{array}{c}-0.34206^{\star *} \\
(-3.51)\end{array}$ & $\begin{array}{c}-0.0977^{* *} \\
(-4.65)\end{array}$ \\
\hline African-American & $\begin{array}{c}-0.40409^{\star *} \\
(-5.81)\end{array}$ & $\begin{array}{c}-0.1644^{\star *} \\
(-12.82)\end{array}$ & $\begin{array}{c}-0.16158 \\
(-0.94)\end{array}$ & $\begin{array}{c}-0.08987^{* *} \\
(-2.76)\end{array}$ \\
\hline Asian & $\begin{array}{c}-0.16566 \\
(-0.89)\end{array}$ & $\begin{array}{c}-0.09797 \\
(-1.41)\end{array}$ & $\begin{array}{c}-0.45227^{\star \star} \\
(-3.65)\end{array}$ & $\begin{array}{c}-0.14988^{\star *} \\
(-4.25)\end{array}$ \\
\hline Other Ethnic Group & -0.1186 & $-0.0734^{\star *}$ & $-0.30695^{\star \star}$ & $-0.08369 * *$ \\
\hline
\end{tabular}




\begin{tabular}{|c|c|c|c|c|}
\hline & $(-0.96)$ & $(-2.24)$ & $(-2.27)$ & $(-2.09)$ \\
\hline Typical Weekly Hours Worked & $\begin{array}{c}0.01096^{* *} \\
(14.36)\end{array}$ & $\begin{array}{c}0.01332^{* *} \\
(33.12)\end{array}$ & $\begin{array}{c}0.01488^{* *} \\
(9.23)\end{array}$ & $\begin{array}{c}0.01268^{\star *} \\
(17)\end{array}$ \\
\hline Years at Job & $\begin{array}{c}0.04812^{\star *} \\
(4.23)\end{array}$ & $\begin{array}{c}0.05544^{* *} \\
(19.65)\end{array}$ & $\begin{array}{c}0.05998^{* *} \\
(2.67)\end{array}$ & $\begin{array}{c}0.06776^{\star *} \\
(10.07)\end{array}$ \\
\hline Years at Job Squared/100 & $\begin{array}{c}-0.21885^{\star *} \\
(-2.97)\end{array}$ & $\begin{array}{c}-0.24186^{\star *} \\
(-12.73)\end{array}$ & $\begin{array}{c}-0.27014^{*} \\
(-1.84)\end{array}$ & $\begin{array}{c}-0.37981^{\star *} \\
(-6.04)\end{array}$ \\
\hline Years at Job Cubed/1000 & $\begin{array}{c}0.02808^{\star *} \\
(2.29)\end{array}$ & $\begin{array}{c}0.03587^{* *} \\
(10.32)\end{array}$ & $\begin{array}{c}0.03615 \\
(1.41)\end{array}$ & $\begin{array}{c}0.06613^{\star *} \\
(4.5)\end{array}$ \\
\hline Years Since Migration & & & $\begin{array}{c}0.00555 \\
(1.02)\end{array}$ & $\begin{array}{c}0.00304^{* *} \\
(2.81)\end{array}$ \\
\hline Years Since Migration Squared & & & $\begin{array}{c}0.04915 \\
(0.3)\end{array}$ & $\begin{array}{c}0.04211^{*} \\
(1.67)\end{array}$ \\
\hline Years Since Migration Cubed & & & $\begin{array}{c}0.01325 \\
(0.11)\end{array}$ & $\begin{array}{c}-0.03102 \\
(-1.11)\end{array}$ \\
\hline Not Naturalized Citizen & & & $\begin{array}{c}0.07855 \\
(0.97)\end{array}$ & $\begin{array}{c}-0.05315^{\star \star} \\
(-3.1)\end{array}$ \\
\hline \multicolumn{5}{|l|}{ Previous Year's Labor Force Status } \\
\hline Wage/Salary & $\begin{array}{c}0.49227^{\star \star} \\
(4.71)\end{array}$ & $\begin{array}{c}0.63193^{\star \star} \\
(26.03)\end{array}$ & $\begin{array}{c}0.48596^{\star \star} \\
(2.23)\end{array}$ & $\begin{array}{c}0.4941^{\star *} \\
(11.97)\end{array}$ \\
\hline Self-Employed & $\begin{array}{c}0.47177^{* *} \\
(4.78)\end{array}$ & $\begin{array}{c}0.47563^{* *} \\
(9.28)\end{array}$ & $\begin{array}{c}0.49752^{\star *} \\
(2.28)\end{array}$ & $\begin{array}{c}0.44972^{* *} \\
(6.53)\end{array}$ \\
\hline Wage/Salary, Less than 15 Hours/Week & $\begin{array}{c}-1.55668^{\star *} \\
(-2.81)\end{array}$ & $\begin{array}{c}0.07941 \\
(1.4)\end{array}$ & & $\begin{array}{c}-0.02763 \\
(-0.26)\end{array}$ \\
\hline Self-Employed, Less than 15 Hours/Week & $\begin{array}{l}0.2267 \\
(1.57)\end{array}$ & $\begin{array}{c}0.55095^{\star *} \\
(7.6)\end{array}$ & $\begin{array}{c}0.16068 \\
(0.52)\end{array}$ & $\begin{array}{c}0.30062^{\star *} \\
(2.11)\end{array}$ \\
\hline Unemployed & $\begin{array}{c}-0.20397 \\
(-1.1)\end{array}$ & $\begin{array}{c}0.14304^{* *} \\
(3.55)\end{array}$ & $\begin{array}{c}-0.29606 \\
(-0.96)\end{array}$ & $\begin{array}{c}0.11788^{\star *} \\
(1.98)\end{array}$ \\
\hline Welfare & $\begin{array}{c}-0.36611 \\
(-1.36)\end{array}$ & $\begin{array}{c}-0.40321^{\star *} \\
(-4.48)\end{array}$ & $\begin{array}{c}-0.76336^{\star} \\
(-1.77)\end{array}$ & $\begin{array}{c}-0.13799 \\
(-1.49)\end{array}$ \\
\hline Constant & $\begin{array}{c}6.687^{\star \star} \\
(8.73)\end{array}$ & $\begin{array}{c}6.14298^{\star \star} \\
(45.71)\end{array}$ & $\begin{array}{c}5.21897^{\star *} \\
(3.68)\end{array}$ & $\begin{array}{c}5.56464^{\star \star} \\
(24.06)\end{array}$ \\
\hline R squared & 0.1548 & 0.4707 & 0.2664 & 0.4231 \\
\hline Number of Observations & 4,620 & 30,377 & 1,224 & 9,466 \\
\hline
\end{tabular}

Source: 1996, 2001 and 2004 Panels of the Survey of Income and Program Participation (SIPP). 
Table 8

Ordinary Least Squares, Log of Total Annual Earnings, Women.

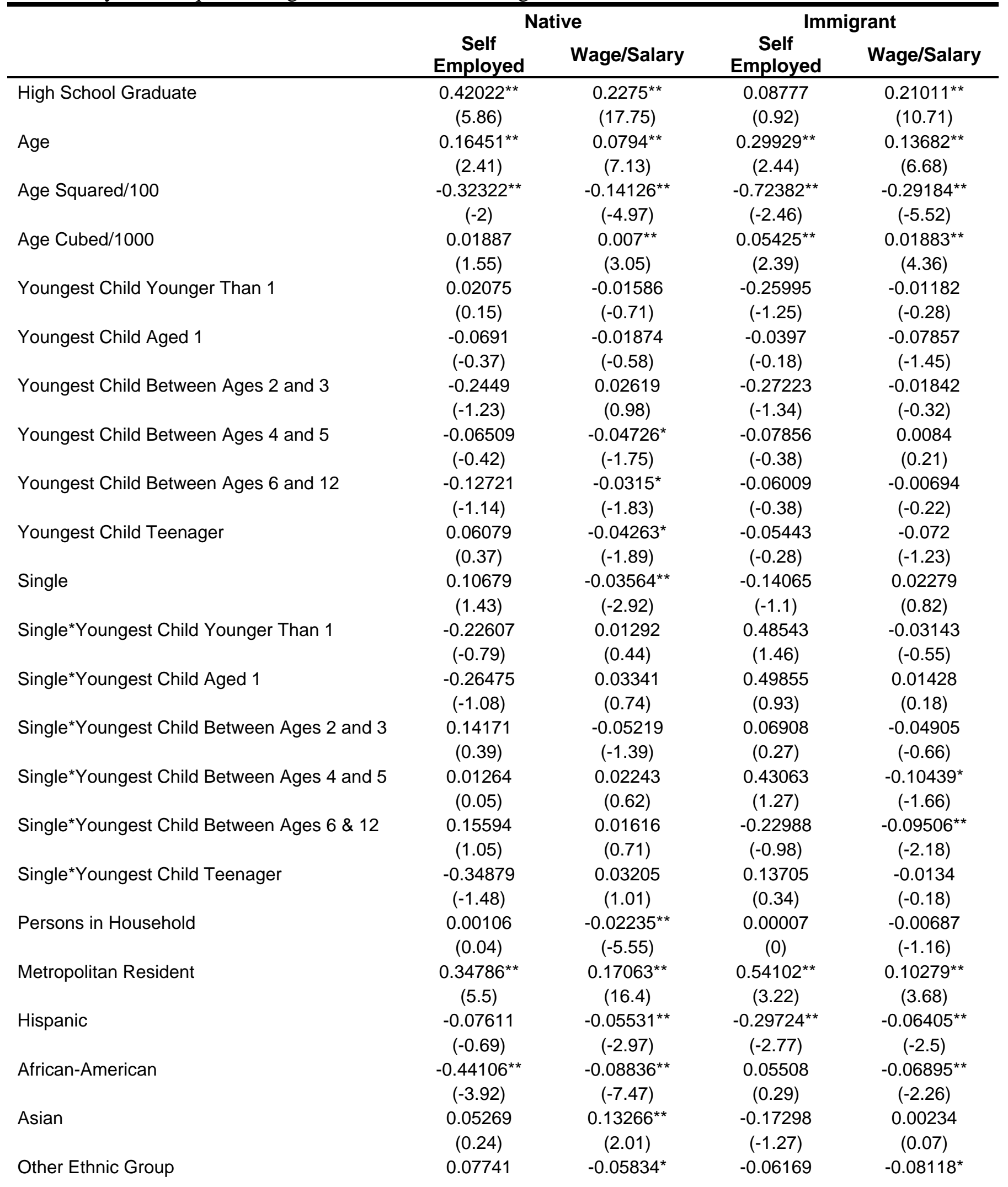




\begin{tabular}{|c|c|c|c|c|}
\hline & $(0.5)$ & $(-1.74)$ & $(-0.35)$ & $(-1.68)$ \\
\hline Typical Weekly Hours Worked & $\begin{array}{c}0.01052^{\star *} \\
(7.28)\end{array}$ & $\begin{array}{c}0.02117^{\star \star} \\
(44.74)\end{array}$ & $\begin{array}{c}0.01334^{\star *} \\
(5.38)\end{array}$ & $\begin{array}{c}0.01956^{\star \star} \\
(21.49)\end{array}$ \\
\hline Years at Job & $\begin{array}{c}0.04933^{\star \star} \\
(2.5)\end{array}$ & $\begin{array}{c}0.07787^{* *} \\
(24.21)\end{array}$ & $\begin{array}{c}0.0527^{\star} \\
(1.73)\end{array}$ & $\begin{array}{c}0.0994^{\star *} \\
(14.27)\end{array}$ \\
\hline Years at Job Squared/100 & $\begin{array}{c}-0.19778 \\
(-1.55)\end{array}$ & $\begin{array}{c}-0.32152^{\star *} \\
(-13.58)\end{array}$ & $\begin{array}{c}-0.16324 \\
(-0.74)\end{array}$ & $\begin{array}{c}-0.49835^{\star \star} \\
(-8.89)\end{array}$ \\
\hline Years at Job Cubed/1000 & $\begin{array}{l}0.0245 \\
(1.11)\end{array}$ & $\begin{array}{c}0.04398^{\star *} \\
(9.23)\end{array}$ & $\begin{array}{c}0.00838 \\
(0.21)\end{array}$ & $\begin{array}{c}0.07915^{\star *} \\
\quad(6.6)\end{array}$ \\
\hline Years Since Migration & & & $\begin{array}{c}0.00511 \\
(0.82)\end{array}$ & $\begin{array}{c}0.00296^{* *} \\
(2.35)\end{array}$ \\
\hline Years Since Migration Squared & & & $\begin{array}{c}-0.08642 \\
(-0.54)\end{array}$ & $\begin{array}{c}0.01628 \\
(0.45)\end{array}$ \\
\hline Years Since Migration Cubed & & & $\begin{array}{c}-0.34334^{* *} \\
(-2.7)\end{array}$ & $\begin{array}{c}-0.00951 \\
(-0.36)\end{array}$ \\
\hline Not Naturalized Citizen & & & $\begin{array}{c}-0.09385 \\
(-0.94)\end{array}$ & $\begin{array}{c}-0.04835^{\star \star} \\
(-2.28)\end{array}$ \\
\hline \multicolumn{5}{|l|}{ Previous Year's Labor Force Status } \\
\hline Wage/Salary & $\begin{array}{c}0.87241^{\star \star} \\
(6.17)\end{array}$ & $\begin{array}{c}0.70602^{\star *} \\
(27.35)\end{array}$ & $\begin{array}{c}0.92871^{\star \star} \\
(4.52)\end{array}$ & $\begin{array}{l}0.578^{\star \star} \\
(16.95)\end{array}$ \\
\hline Self-Employed & $\begin{array}{c}0.88404^{\star *} \\
(6.8)\end{array}$ & $\begin{array}{l}0.54^{\star *} \\
(7.71)\end{array}$ & $\begin{array}{c}1.09228^{* *} \\
(6.28)\end{array}$ & $\begin{array}{c}0.33951^{* *} \\
(2.54)\end{array}$ \\
\hline Wage/Salary, Less than 15 Hours/Week & $\begin{array}{c}0.42041 \\
(1.37)\end{array}$ & $\begin{array}{c}0.13781^{\star *} \\
(3.24)\end{array}$ & $\begin{array}{c}-0.64615 \\
(-0.96)\end{array}$ & $\begin{array}{c}0.13505^{\star} \\
(1.78)\end{array}$ \\
\hline Self-Employed, Less than 15 Hours/Week & $\begin{array}{c}0.62188^{\star \star} \\
(3.39)\end{array}$ & $\begin{array}{c}0.51075^{\star *} \\
(6.92)\end{array}$ & $\begin{array}{c}0.93818^{* *} \\
(3.41)\end{array}$ & $\begin{array}{c}0.20752 \\
(0.7)\end{array}$ \\
\hline Unemployed & $\begin{array}{c}0.10547 \\
(0.37)\end{array}$ & $\begin{array}{c}0.22097^{\star *} \\
(5.52)\end{array}$ & $\begin{array}{c}0.56595^{\star} \\
(1.66)\end{array}$ & $\begin{array}{c}0.08841 \\
(1.44)\end{array}$ \\
\hline Welfare & $\begin{array}{c}-0.39265 \\
(-1.22)\end{array}$ & $\begin{array}{c}-0.20739^{\star *} \\
(-4.69)\end{array}$ & $\begin{array}{c}0.14547 \\
(0.4)\end{array}$ & $\begin{array}{c}-0.11906^{*} \\
(-1.78)\end{array}$ \\
\hline Constant & $\begin{array}{c}4.86301^{\star *} \\
(5.27)\end{array}$ & $\begin{array}{c}6.52221^{\star *} \\
(49.69)\end{array}$ & $\begin{array}{c}3.57399^{\star *} \\
(2.25)\end{array}$ & $\begin{array}{c}5.99562^{\star \star} \\
(24.67)\end{array}$ \\
\hline R squared & 0.2191 & 0.4813 & 0.3999 & 0.4968 \\
\hline Number of Observations & 2,011 & 27,888 & 604 & 6,807 \\
\hline
\end{tabular}

Note: t-statistics are shown in parentheses. Standard errors are adjusted for individual repeated observations, i.e. clusters. 
Table 9

Logit Models of Business Start-Up Probability, Marginal Effects

\begin{tabular}{|c|c|c|c|c|}
\hline \multirow[b]{2}{*}{ Variable } & \multicolumn{2}{|c|}{ Native } & \multicolumn{2}{|c|}{ Immigrant } \\
\hline & Men & Women & Men & Women \\
\hline High School Graduate & $\begin{array}{c}-0.00233 \\
(-1.2)\end{array}$ & $\begin{array}{c}-0.00216 \\
(-1.35)\end{array}$ & $\begin{array}{c}0.00411 \\
(1.34)\end{array}$ & $\begin{array}{c}-0.00119 \\
(-0.42)\end{array}$ \\
\hline Age & $\begin{array}{c}0.01488^{\star \star} \\
(7.61)\end{array}$ & $\begin{array}{c}0.00102 \\
(0.69)\end{array}$ & $\begin{array}{c}0.01638^{\star *} \\
(4)\end{array}$ & $\begin{array}{c}0.00112 \\
(0.33)\end{array}$ \\
\hline Age Squared/100 & $\begin{array}{c}-.03462^{\star *} \\
(-6.95)\end{array}$ & $\begin{array}{c}-0.0013 \\
(-0.35)\end{array}$ & $\begin{array}{c}-0.03638^{\star \star} \\
(-3.46)\end{array}$ & $\begin{array}{c}0.00019 \\
(0.02)\end{array}$ \\
\hline Age Cubed/1000 & $\begin{array}{c}0.00257^{\star *} \\
(6.41)\end{array}$ & $\begin{array}{c}0.00006 \\
(0.18)\end{array}$ & $\begin{array}{c}0.00261^{* *} \\
(3.03)\end{array}$ & $\begin{array}{c}-0.00016 \\
(-0.22)\end{array}$ \\
\hline Youngest Child Younger Than 1 & $\begin{array}{c}-0.00077 \\
(-0.26)\end{array}$ & $\begin{array}{c}0.00656^{\star} \\
(1.67)\end{array}$ & $\begin{array}{c}0.00812 \\
(1.12)\end{array}$ & $\begin{array}{c}0.00082 \\
(0.16)\end{array}$ \\
\hline Youngest Child Aged 1 & $\begin{array}{c}-0.00478 \\
(-1.48)\end{array}$ & $\begin{array}{c}0.00878 \\
(1.32)\end{array}$ & $\begin{array}{c}0.00823 \\
(0.74)\end{array}$ & $\begin{array}{c}0.00474 \\
(0.49)\end{array}$ \\
\hline Youngest Child Between Ages 2 and 3 & $\begin{array}{c}-0.00096 \\
(-0.28)\end{array}$ & $\begin{array}{c}-0.0014 \\
(-0.47)\end{array}$ & $\begin{array}{c}0.00769 \\
(0.86)\end{array}$ & $\begin{array}{c}0.01065 \\
(1.23)\end{array}$ \\
\hline Youngest Child Between Ages 4 and 5 & $\begin{array}{c}-0.00094 \\
(-0.28)\end{array}$ & $\begin{array}{c}0.0003 \\
(0.1)\end{array}$ & $\begin{array}{c}0.01544 \\
(1.44)\end{array}$ & $\begin{array}{c}-0.00785^{\star *} \\
(-2.39)\end{array}$ \\
\hline Youngest Child Between Ages 6 and 12 & $\begin{array}{c}-0.00298 \\
(-1.3)\end{array}$ & $\begin{array}{c}0.0015 \\
(0.63)\end{array}$ & $\begin{array}{c}0.0009 \\
(0.16)\end{array}$ & $\begin{array}{c}0.00049 \\
(0.12)\end{array}$ \\
\hline Youngest Child Teenager & $\begin{array}{c}0.00475 \\
(1.15)\end{array}$ & $\begin{array}{l}-0.002 \\
(-0.97)\end{array}$ & $\begin{array}{c}0.01838 \\
(1.4)\end{array}$ & $\begin{array}{c}0.00307 \\
(0.39)\end{array}$ \\
\hline Single & $\begin{array}{c}-0.00279 \\
(-1.38)\end{array}$ & $\begin{array}{c}-0.00103 \\
(-0.64)\end{array}$ & $\begin{array}{c}0.00054 \\
(0.11)\end{array}$ & $\begin{array}{c}-0.00429 \\
(-1.1)\end{array}$ \\
\hline Single*Youngest Child Younger Than 1 & $\begin{array}{c}-0.00217 \\
(-0.47)\end{array}$ & $\begin{array}{c}-0.00501^{\star *} \\
(-2.81)\end{array}$ & $\begin{array}{c}-0.00443 \\
(-0.57)\end{array}$ & $\begin{array}{c}-0.00228 \\
(-0.35)\end{array}$ \\
\hline Single*Youngest Child Aged 1 & $\begin{array}{c}0.04064 \\
(1.54)\end{array}$ & $\begin{array}{c}-0.0065^{\star *} \\
(-3.2)\end{array}$ & $\begin{array}{c}-0.01201^{*} \\
(-1.85)\end{array}$ & $\begin{array}{c}-0.00407 \\
(-0.62)\end{array}$ \\
\hline Single ${ }^{\star}$ Youngest Child Ages 2 and 3 & $\begin{array}{c}0.00224 \\
(0.28)\end{array}$ & $\begin{array}{c}0.00278 \\
(0.42)\end{array}$ & $\begin{array}{c}-0.00699 \\
(-0.94)\end{array}$ & $\begin{array}{c}0.01198 \\
(0.81)\end{array}$ \\
\hline Single ${ }^{\star}$ Youngest Child Ages 4 and 5 & $\begin{array}{c}0.01004 \\
(0.69)\end{array}$ & $\begin{array}{c}-0.00277 \\
(-0.83)\end{array}$ & $\begin{array}{c}-0.01039 * \\
(-1.9)\end{array}$ & $\begin{array}{c}0.07629 \\
(1.1)\end{array}$ \\
\hline Single*Youngest Child Ages 6 and 12 & $\begin{array}{c}0.00629 \\
(1.11)\end{array}$ & $\begin{array}{c}-0.00348 \\
(-1.55)\end{array}$ & $\begin{array}{c}0.01017 \\
(0.7)\end{array}$ & $\begin{array}{c}0.00145 \\
(0.19)\end{array}$ \\
\hline Single*Youngest Child Teenager & $\begin{array}{c}-0.00333 \\
(-0.65)\end{array}$ & $\begin{array}{c}0.00016 \\
(0.04)\end{array}$ & $\begin{array}{c}-0.01566^{\star \star} \\
(-4.36)\end{array}$ & $\begin{array}{c}-0.00555 \\
(-1.1)\end{array}$ \\
\hline Persons in Household & $\begin{array}{c}0.00023 \\
(0.37)\end{array}$ & $\begin{array}{c}0.00027 \\
(0.59)\end{array}$ & $\begin{array}{c}-0.00092 \\
(-0.97)\end{array}$ & $\begin{array}{c}0.0005 \\
(0.61)\end{array}$ \\
\hline Metropolitan Resident & $\begin{array}{c}-0.00133 \\
(-0.84)\end{array}$ & $\begin{array}{c}0.00064 \\
(0.54)\end{array}$ & $\begin{array}{c}-0.00064 \\
(-0.17)\end{array}$ & $\begin{array}{c}-0.00022 \\
(-0.07)\end{array}$ \\
\hline California & $\begin{array}{c}0.00238 \\
(0.82)\end{array}$ & $\begin{array}{c}0.00115 \\
(0.48)\end{array}$ & $\begin{array}{c}-0.00327 \\
(-0.86)\end{array}$ & $\begin{array}{c}-0.00065 \\
(-0.2)\end{array}$ \\
\hline Texas & -0.0016 & 0.00156 & 0.00907 & -0.00026 \\
\hline
\end{tabular}


New York

Florida

Illinois

Pennsylvania

Ohio

Michigan

New Jersey

Georgia

Western States

Hispanic

African-American

Asian

Other Ethnic Group

Not Naturalized Citizen

Years Since Migration

Years Since Migration Squared

Years Since Migration Cubed

Household Net Worth, 2nd Quintile

Household Net Worth, 3rd Quintile

Household Net Worth, 4th Quintile

Household Net Worth, Top Quintile

\begin{tabular}{|c|c|c|c|}
\hline$(-0.62)$ & $(0.66)$ & $(1.48)$ & $(-0.06)$ \\
\hline$-0.00428^{*}$ & 0.00125 & 0.003 & $-0.00731^{\star *}$ \\
\hline$(-1.67)$ & $(0.48)$ & $(0.45)$ & $(-2.59)$ \\
\hline-0.0001 & 0.00142 & 0.00544 & -0.003 \\
\hline$(-0.03)$ & $(0.49)$ & $(0.86)$ & $(-0.98)$ \\
\hline$-0.00435^{\star}$ & -0.00191 & $-0.00996^{\star \star}$ & -0.00458 \\
\hline$(-1.74)$ & $(-0.83)$ & $(-2.25)$ & $(-1.09)$ \\
\hline$-0.0059 * *$ & $-0.00624^{\star *}$ & -0.00619 & -0.00329 \\
\hline$(-2.6)$ & $(-4.52)$ & $(-0.82)$ & $(-0.64)$ \\
\hline-0.00194 & -0.0007 & -0.0023 & $-0.00645^{\star}$ \\
\hline$(-0.81)$ & $(-0.33)$ & $(-0.26)$ & $(-1.67)$ \\
\hline-0.0003 & -0.00241 & -0.00581 & $-0.00961^{* *}$ \\
\hline$(-0.07)$ & $(-1.05)$ & $(-0.82)$ & $(-4.01)$ \\
\hline 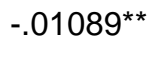 & -0.00196 & -0.00497 & $-0.0082^{\star *}$ \\
\hline$(-4.57)$ & $(-0.63)$ & $(-0.87)$ & $(-3.1)$ \\
\hline 0.0063 & 0.00211 & $-0.00968^{*}$ & $-0.01028 * *$ \\
\hline (1.28) & $(0.68)$ & $(-1.93)$ & $(-5.02)$ \\
\hline-0.00045 & 0.00185 & 0.00222 & $-0.00589 * *$ \\
\hline$(-0.19)$ & $(0.86)$ & $(0.35)$ & $(-2.27)$ \\
\hline-0.00065 & -0.00055 & -0.00128 & -0.00076 \\
\hline$(-0.26)$ & $(-0.29)$ & $(-0.33)$ & $(-0.25)$ \\
\hline$-.00535^{\star \star}$ & -0.00198 & -0.00317 & -0.0032 \\
\hline$(-3.12)$ & $(-1.29)$ & $(-0.65)$ & $(-0.85)$ \\
\hline-0.00204 & & 0.00307 & -0.00317 \\
\hline$(-0.28)$ & & $(0.47)$ & $(-0.99)$ \\
\hline-0.00364 & 0.0026 & -0.00023 & -0.00288 \\
\hline \multirow[t]{9}{*}{$(-1.11)$} & $(0.75)$ & $(-0.03)$ & $(-0.67)$ \\
\hline & & -0.00422 & -0.00103 \\
\hline & & $(-1.3)$ & $(-0.35)$ \\
\hline & & -0.00027 & -0.00016 \\
\hline & & $(-1.41)$ & $(-1.2)$ \\
\hline & & $-0.00874^{\star \star}$ & 0.00232 \\
\hline & & $(-2.49)$ & $(0.5)$ \\
\hline & & -0.00358 & 0.00077 \\
\hline & & $(-0.92)$ & $(0.19)$ \\
\hline-0.00157 & -0.00145 & 0.0007 & -0.00079 \\
\hline$(-0.78)$ & $(-0.87)$ & (0.18) & $(-0.25)$ \\
\hline 0.00001 & 0.00342 & -0.00161 & -0.00298 \\
\hline$(0.01)$ & $(1.6)$ & $(-0.37)$ & $(-1.00)$ \\
\hline 0.00143 & 0.00238 & 0.00085 & 0.0004 \\
\hline$(0.63)$ & (1.19) & $(0.18)$ & $(0.1)$ \\
\hline 0.00377 & $0.00361^{*}$ & 0.00426 & 0.00249 \\
\hline$(1.46)$ & $(1.78)$ & $(0.75)$ & $(0.59)$ \\
\hline
\end{tabular}




\begin{tabular}{|c|c|c|c|c|}
\hline Years at Job & $\begin{array}{c}-.00479 * * \\
(-7.91)\end{array}$ & $\begin{array}{c}-0.00231^{\star *} \\
(-3.96)\end{array}$ & $\begin{array}{c}-0.00471^{\star \star} \\
(-4.12)\end{array}$ & $\begin{array}{c}-0.00417^{\star *} \\
(-3.15)\end{array}$ \\
\hline Years at Job Squared/100 & $\begin{array}{c}0.02502^{\star *} \\
(5.34)\end{array}$ & $\begin{array}{c}0.01445^{\star \star} \\
(2.96)\end{array}$ & $\begin{array}{c}0.02415^{\star \star} \\
(2.97)\end{array}$ & $\begin{array}{c}0.03592^{* *} \\
(2.95)\end{array}$ \\
\hline Years at Job Cubed/1000 & $\begin{array}{c}-.00357^{\star *} \\
(-3.79)\end{array}$ & $\begin{array}{c}-0.00264^{\star *} \\
(-2.44)\end{array}$ & $\begin{array}{c}-0.00281^{*} \\
(-1.83)\end{array}$ & $\begin{array}{c}-0.00798 * \star \\
(-2.72)\end{array}$ \\
\hline \multicolumn{5}{|l|}{ Previous Year's Labor Force Status } \\
\hline Self-Employed, Less than 15 Hours/Week & $\begin{array}{c}0.59035^{\star *} \\
(13.69)\end{array}$ & $\begin{array}{c}0.58475^{\star *} \\
(12.86)\end{array}$ & $\begin{array}{c}0.62178^{\star *} \\
(5.74)\end{array}$ & $\begin{array}{c}0.81142^{\star *} \\
(10.82)\end{array}$ \\
\hline Wage/Salary, Less than 15 Hours/Week & $\begin{array}{c}0.00931 \\
(0.79)\end{array}$ & $\begin{array}{c}0.01682^{*} \\
(1.9)\end{array}$ & & $\begin{array}{c}0.01049 \\
(0.76)\end{array}$ \\
\hline Unemployed & $\begin{array}{c}0.01471^{* *} \\
(2.85)\end{array}$ & $\begin{array}{c}0.02336^{\star \star} \\
(2.83)\end{array}$ & $\begin{array}{c}0.02466^{\star \star} \\
(2.22)\end{array}$ & $\begin{array}{c}0.02082 \\
(1.54)\end{array}$ \\
\hline Welfare & $\begin{array}{c}0.04438^{\star *} \\
(2.97)\end{array}$ & $\begin{array}{c}0.02762^{\star *} \\
(3.08)\end{array}$ & $\begin{array}{c}0.05273^{*} \\
(1.94)\end{array}$ & $\begin{array}{c}0.03781^{*} \\
(1.87)\end{array}$ \\
\hline Not in the Labor Force & $\begin{array}{c}0.04687^{\star \star} \\
(5.02)\end{array}$ & $\begin{array}{c}0.04821^{\star \star} \\
(5.54)\end{array}$ & $\begin{array}{c}0.09584^{\star *} \\
(4.16)\end{array}$ & $\begin{array}{c}0.04929 * * \\
(3.45)\end{array}$ \\
\hline Pseudo R squared & 0.2015 & 0.2389 & 0.1654 & 0.2358 \\
\hline Number of Observations & 27,399 & 25,016 & 8,245 & 5,794 \\
\hline
\end{tabular}




\section{Figures}

Figure 1

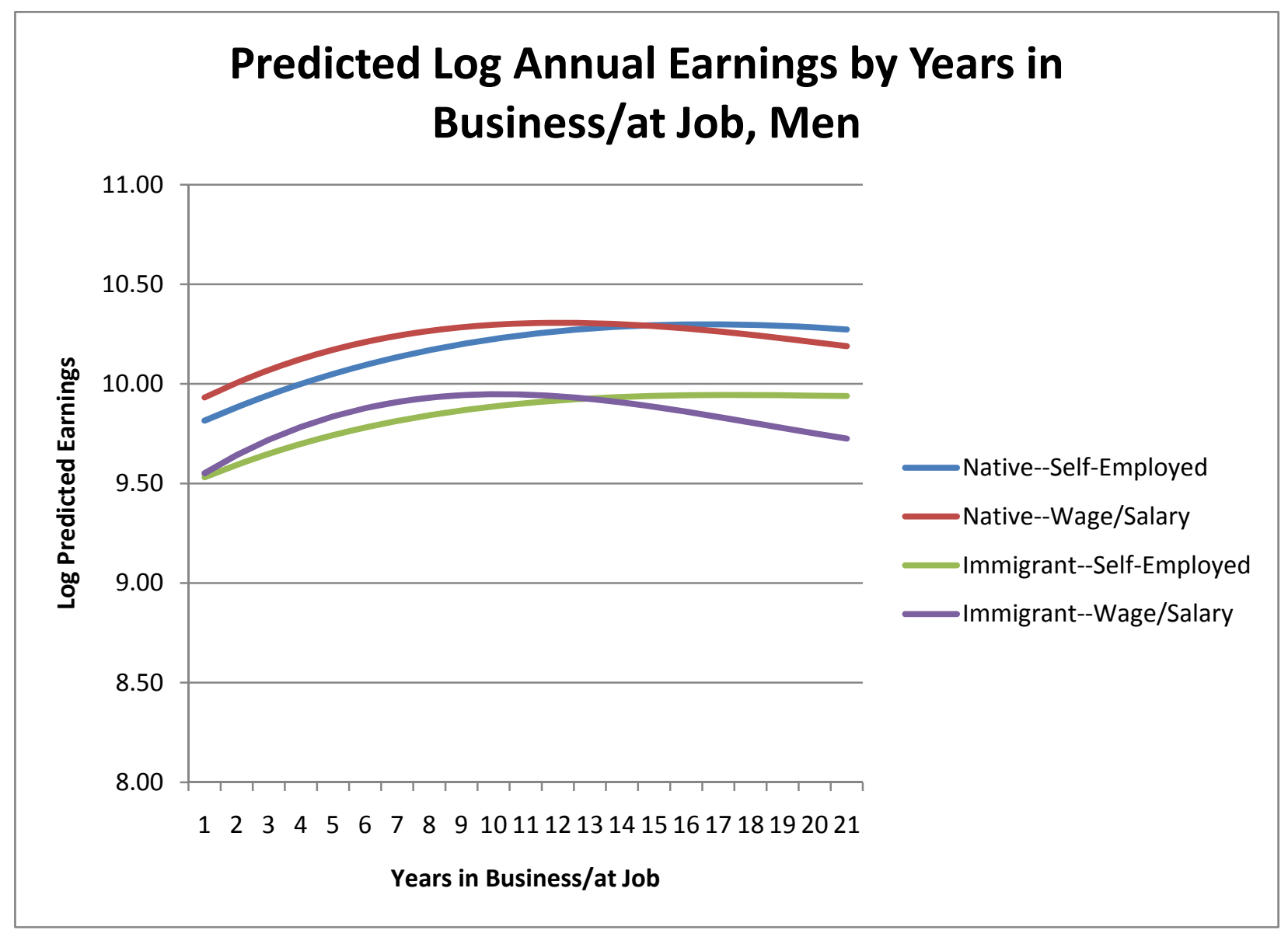

Note: The predicted log annual earnings are generated from the regression estimates presented in Appendix Table A2. 
Figure 2

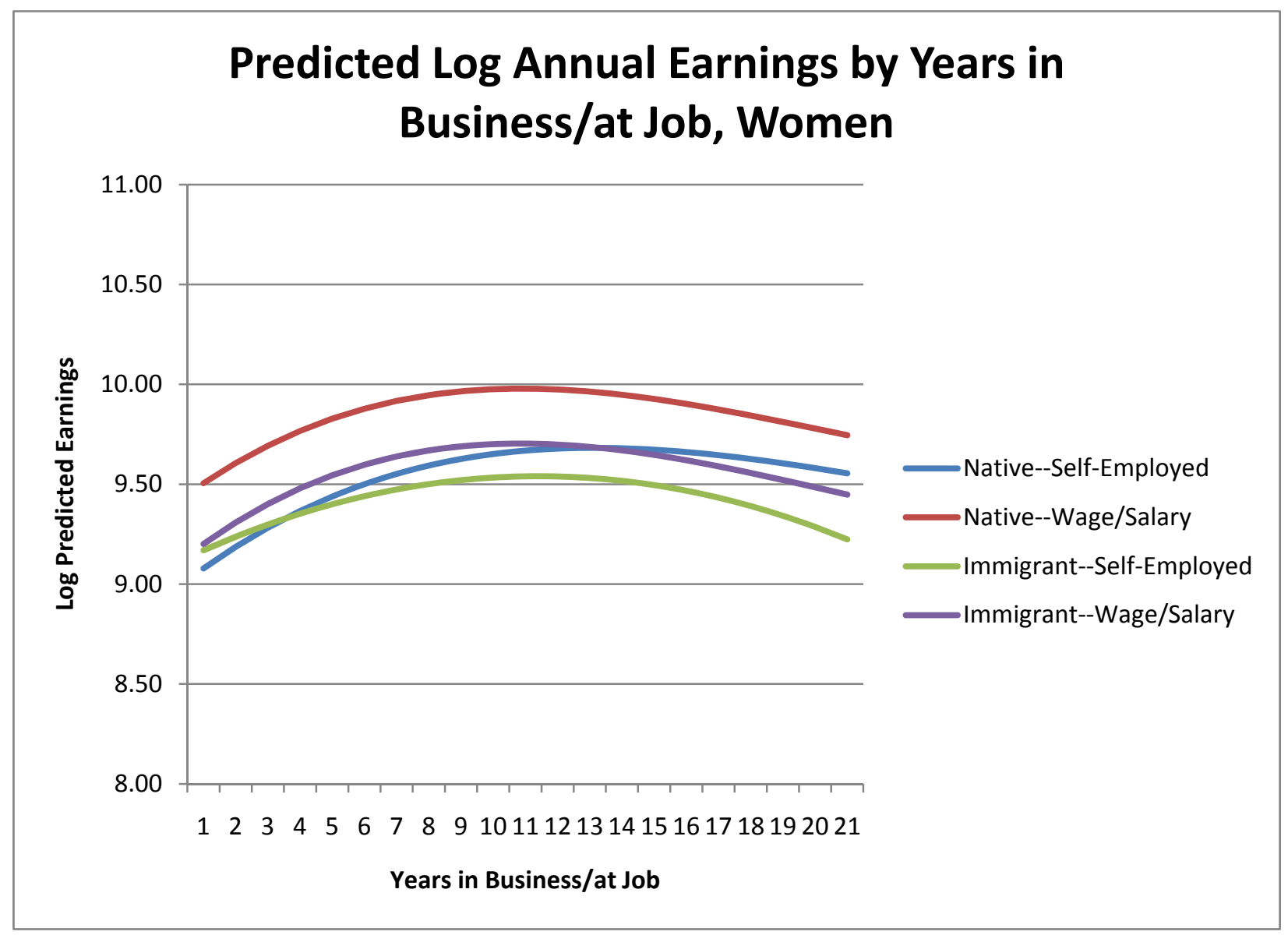

Note: The predicted log annual earnings are generated from the regression estimates presented in Appendix Table A3. 


\section{Appendix}

Table A1

Oaxaca Decomposition of Log Total Annual Earnings, Self-Employment and Wage/Salary Employment.

\begin{tabular}{|c|c|c|c|c|}
\hline & \multicolumn{2}{|c|}{ Men } & \multicolumn{2}{|c|}{ Women } \\
\hline & Native & Immigrant & Native & Immigrant \\
\hline $\begin{array}{c}\text { Observed Mean Wage/Salary Advantage, } \\
\text { Total Annual Earnings }\end{array}$ & $3.8 \%$ & $4.3 \%$ & $39.4 \%$ & $15.0 \%$ \\
\hline \multicolumn{5}{|l|}{ Contribution due to } \\
\hline Education & $-0.01 \%$ & $-0.4 \%$ & $0.3 \%$ & $-0.1 \%$ \\
\hline Age & $-3.3 \%$ & $-5.7 \%$ & $-3.0 \%$ & $-3.1 \%$ \\
\hline Household Composition & $-3.7 \%$ & $-2.5 \%$ & $0.9 \%$ & $-0.9 \%$ \\
\hline Geographic Location & $1.7 \%$ & $2.2 \%$ & $0.5 \%$ & $-5.6 \%$ \\
\hline Ethnic Composition & $-3.4 \%$ & $-1.7 \%$ & $-3.6 \%$ & $1.5 \%$ \\
\hline Hours Work per Week & $-7.7 \%$ & $-8.5 \%$ & $-4.9 \%$ & $0.5 \%$ \\
\hline Years in Business/Job & $-4.4 \%$ & $-4.5 \%$ & $-3.7 \%$ & $-0.6 \%$ \\
\hline Previous Labor Market Status & $-3.3 \%$ & $-3.9 \%$ & $-3.3 \%$ & $-4.3 \%$ \\
\hline Year Effects & $-0.01 \%$ & $-0.3 \%$ & $-0.3 \%$ & $-5.0 \%$ \\
\hline Not Naturalized & $\mathrm{N} / \mathrm{A}$ & $0.5 \%$ & N/A & $-18.4 \%$ \\
\hline Years in the U.S. & N/A & $-0.8 \%$ & N/A & $-0.5 \%$ \\
\hline Total Due to Characteristics & $-24.1 \%$ & $-25.7 \%$ & $-17.2 \%$ & $-36.5 \%$ \\
\hline
\end{tabular}

Note: Based on sample means and regressions results presented in Tables 2-3 and Tables 8-9. 
Table A2

Fixed Effects Log Annual Earnings Models, Men

\begin{tabular}{lcccc}
\hline & \multicolumn{2}{c}{ Native } & \multicolumn{2}{c}{ Immigrant } \\
& $\begin{array}{c}\text { Self } \\
\text { Employed }\end{array}$ & Wage/Salary & $\begin{array}{c}\text { Self } \\
\text { Employed }\end{array}$ & Wage/Salary \\
\hline Typical Weekly Hours Worked & $0.0059^{* *}$ & $0.0055^{* *}$ & $0.0098^{* *}$ & $0.0066^{* *}$ \\
& $(4.27)$ & $(13.99)$ & $(2.87)$ & $(8.73)$ \\
Years in Business/at Job & $0.0701^{* *}$ & $0.0778^{* *}$ & $0.0653^{*}$ & $0.098^{* *}$ \\
& $(3.05)$ & $(17.48)$ & $(1.75)$ & $(10.15)$ \\
Years in Business/at Job ${ }^{2} / 100$ & $-0.3032^{* *}$ & $-0.4858^{* *}$ & $-0.337^{*}$ & $-0.7242^{* *}$ \\
& $(-2.04)$ & $(-13.85)$ & $(-1.74)$ & $(-8.09)$ \\
Years in Business/at Job ${ }^{3} / 1000$ & 0.034 & $0.0806^{* *}$ & 0.056 & $0.1388^{* *}$ \\
& $(1.27)$ & $(11.6)$ & $(1.48)$ & $(6.31)$ \\
Constant & $9.5505^{* *}$ & $9.6865^{* *}$ & $9.0906^{* *}$ & $9.256^{* *}$ \\
& $(75.73)$ & $(444.68)$ & $(44.79)$ & $(226.58)$ \\
R squared within & & & & 0.1002 \\
R squared between & 0.0180 & 0.0559 & 0.0380 & 0.1002 \\
R squared overall & 0.0784 & 0.2780 & 0.0933 & 0.0507 \\
Number of Observations & 0.0596 & 0.2039 & 0.0972 & 0.0722 \\
\hline
\end{tabular}

Note: t-statistics are shown in parentheses.

Table A3

Fixed Effects Log Annual Earnings Models, Women

\begin{tabular}{lcccc} 
& \multicolumn{2}{c}{ Native } & \multicolumn{2}{c}{ Immigrant } \\
& $\begin{array}{c}\text { Self } \\
\text { Employed }\end{array}$ & Wage/Salary & $\begin{array}{c}\text { Self } \\
\text { Employed }\end{array}$ & Wage Salary \\
\hline Typical Weekly Hours Worked & $0.0075^{* *}$ & $0.0091^{* *}$ & $0.0105^{* *}$ & $0.0105^{* *}$ \\
& $(3.34)$ & $(19.67)$ & $(3.57)$ & $(9.27)$ \\
Years in Business/at Job & $0.1146^{* *}$ & $0.1081^{* *}$ & $0.0713^{*}$ & $0.1151^{* *}$ \\
& $(2.52)$ & $(21.17)$ & $(1.74)$ & $(9.47)$ \\
Years in Business/at Job ${ }^{2} / 100$ & $-0.6583^{* *}$ & $-0.7356^{* *}$ & $-0.343^{*}$ & $-0.7831^{* *}$ \\
& $(-1.96)$ & $(-15.87)$ & $(-1.68)$ & $(-6.6)$ \\
Years in Business/at Job ${ }^{3} / 1000$ & 0.102 & $0.1274^{* *}$ & & $0.1348^{* *}$ \\
& $(1.45)$ & $(12.12)$ & & $(4.91)$ \\
Constant & $8.7411^{* *}$ & $9.0955^{* *}$ & $8.6986^{* *}$ & $8.7275^{* *}$ \\
& $(49.47)$ & $(397.64)$ & $(41.23)$ & $(165.91)$ \\
R squared within & & & & 0.1415 \\
R squared between & 0.0273 & 0.0932 & 0.0627 & 0.0918 \\
R squared overall & 0.1354 & 0.2711 & 0.0274 & 0.1217 \\
Number of Observations & 0.0940 & 0.2149 & 0.0378 & 0.1217 \\
\hline
\end{tabular}

Note: t-statistics are shown in parentheses. 
Table A4

Descriptive Statistics by Self-Employment Entry, U.S. Born

\begin{tabular}{|c|c|c|c|c|}
\hline & \multicolumn{2}{|c|}{ Men } & \multicolumn{2}{|c|}{ Women } \\
\hline & Entrant & $\begin{array}{c}\text { Non- } \\
\text { Entrant }\end{array}$ & Entrant & $\begin{array}{l}\text { Non- } \\
\text { Entrant }\end{array}$ \\
\hline Self-Employment Entry Rate & \multicolumn{2}{|c|}{$2.58 \%$} & \multicolumn{2}{|c|}{$1.96 \%$} \\
\hline High School Graduate & $80.93 \%$ & $83.70 \%$ & $81.19 \%$ & $86.46 \%$ \\
\hline Age & 39.15 & 38.65 & 41.98 & 40.71 \\
\hline Youngest Child Younger Than 1 & $11.86 \%$ & $10.83 \%$ & $12.45 \%$ & $10.02 \%$ \\
\hline Youngest Child Aged 1 & $3.66 \%$ & $3.14 \%$ & $5.55 \%$ & $3.83 \%$ \\
\hline $\begin{array}{l}\text { Youngest Child Between Ages } 2 \text { and } 3 \\
\text { Youngest Child Between Ages } 4 \text { and } 5 \\
\text { Youngest Child Between Ages } 6 \text { and } 12 \\
\text { Youngest Child Teenager } \\
\text { Single } \\
\text { Persons in Household }\end{array}$ & $\begin{array}{c}5.22 \% \\
4.84 \% \\
13.40 \% \\
5.98 \% \\
41.79 \% \\
3.25\end{array}$ & $\begin{array}{c}5.20 \% \\
4.01 \% \\
14.31 \% \\
5.83 \% \\
44.92 \% \\
3.21\end{array}$ & $\begin{array}{c}6.44 \% \\
4.77 \% \\
18.55 \% \\
5.87 \% \\
32.87 \% \\
3.36\end{array}$ & $\begin{array}{c}5.85 \% \\
5.47 \% \\
17.11 \% \\
6.55 \% \\
45.77 \% \\
3.14\end{array}$ \\
\hline Metropolitan Resident & $67.63 \%$ & $71.88 \%$ & $72.54 \%$ & $73.93 \%$ \\
\hline White & $77.92 \%$ & $75.31 \%$ & $77.93 \%$ & $73.74 \%$ \\
\hline Hispanic & $10.83 \%$ & $9.93 \%$ & $9.39 \%$ & $8.31 \%$ \\
\hline African-American & $9.12 \%$ & $12.86 \%$ & $9.87 \%$ & $15.84 \%$ \\
\hline Asian & $0.30 \%$ & $0.35 \%$ & & $0.34 \%$ \\
\hline Other Ethnic Group & $1.84 \%$ & $1.55 \%$ & $2.81 \%$ & $1.78 \%$ \\
\hline Years at Job & 4.79 & 8.04 & 4.21 & 7.04 \\
\hline \multicolumn{5}{|l|}{ Previous Year's Labor Force Status } \\
\hline Household Net Worth & 122,801 & 102,834 & 148,320 & 115,408 \\
\hline Self-Employed, Less than 15 Hours/Week & $18.57 \%$ & $0.33 \%$ & $21.43 \%$ & $0.31 \%$ \\
\hline Wage/Salary & $54.52 \%$ & $89.60 \%$ & $37.57 \%$ & $86.59 \%$ \\
\hline Wage/Salary, Less than 15 Hours/Week & $0.51 \%$ & $0.58 \%$ & $1.96 \%$ & $1.38 \%$ \\
\hline Unemployed & $7.47 \%$ & $3.76 \%$ & $6.35 \%$ & $3.08 \%$ \\
\hline Welfare & $3.00 \%$ & $1.03 \%$ & $5.18 \%$ & $2.61 \%$ \\
\hline Not in the Labor Force & $15.93 \%$ & $4.71 \%$ & $27.51 \%$ & $6.03 \%$ \\
\hline Number of Observations & 732 & 26,667 & 487 & 24,601 \\
\hline
\end{tabular}


Table A5

Descriptive Statistics by Self-Employment Entry, Foreign Born

\begin{tabular}{|c|c|c|c|c|}
\hline & \multicolumn{2}{|c|}{ Men } & \multicolumn{2}{|c|}{ Women } \\
\hline & Entrant & $\begin{array}{c}\text { Non- } \\
\text { Entrant }\end{array}$ & Entrant & $\begin{array}{c}\text { Non- } \\
\text { Entrant }\end{array}$ \\
\hline Self-Employment Entry Rate & \multicolumn{2}{|c|}{$3.09 \%$} & \multicolumn{2}{|c|}{$2.68 \%$} \\
\hline High School Graduate & $63.96 \%$ & $58.91 \%$ & $57.59 \%$ & $65.94 \%$ \\
\hline Age & 39.29 & 36.90 & 41.75 & 39.83 \\
\hline Youngest Child Younger Than 1 & $19.77 \%$ & $18.46 \%$ & $14.88 \%$ & $13.57 \%$ \\
\hline Youngest Child Aged 1 & $5.12 \%$ & $5.64 \%$ & $6.70 \%$ & $5.74 \%$ \\
\hline $\begin{array}{l}\text { Youngest Child Between Ages } 2 \text { and } 3 \\
\text { Youngest Child Between Ages } 4 \text { and } 5 \\
\text { Youngest Child Between Ages } 6 \text { and } 12 \\
\text { Youngest Child Teenager } \\
\text { Single } \\
\text { Persons in Household }\end{array}$ & $\begin{array}{c}8.43 \% \\
8.09 \% \\
12.73 \% \\
5.13 \% \\
36.37 \% \\
3.97\end{array}$ & $\begin{array}{c}7.40 \% \\
6.37 \% \\
15.02 \% \\
4.94 \% \\
42.64 \% \\
4.05\end{array}$ & $\begin{array}{c}15.38 \% \\
4.94 \% \\
21.47 \% \\
5.55 \% \\
33.55 \% \\
4.21\end{array}$ & $\begin{array}{c}7.39 \% \\
7.06 \% \\
20.64 \% \\
6.32 \% \\
43.03 \% \\
3.86\end{array}$ \\
\hline Metropolitan Resident & $85.16 \%$ & $87.14 \%$ & $87.55 \%$ & $88.28 \%$ \\
\hline White & $27.83 \%$ & $25.63 \%$ & $24.77 \%$ & $27.77 \%$ \\
\hline Hispanic & $55.73 \%$ & $59.81 \%$ & $56.30 \%$ & $49.22 \%$ \\
\hline African-American & $6.79 \%$ & $6.79 \%$ & $5.63 \%$ & $9.52 \%$ \\
\hline Asian & $6.48 \%$ & $5.17 \%$ & $9.95 \%$ & $9.80 \%$ \\
\hline Other Ethnic Group & $3.18 \%$ & $2.59 \%$ & $3.35 \%$ & $3.69 \%$ \\
\hline Not Naturalized Citizen & $46.12 \%$ & $52.26 \%$ & $52.67 \%$ & $47.14 \%$ \\
\hline Years Since Migration & 17.57 & 17.03 & 16.94 & 17.29 \\
\hline Years at Job & 4.56 & 5.50 & 3.35 & 5.04 \\
\hline \multicolumn{5}{|l|}{ Previous Year's Labor Force Status } \\
\hline Household Net Worth & 60,809 & 60,175 & 93,316 & 84,456 \\
\hline Self-Employed, Less than 15 Hours/Week & $8.72 \%$ & $0.17 \%$ & $11.98 \%$ & $0.16 \%$ \\
\hline Wage/Salary & $57.72 \%$ & $89.09 \%$ & $33.96 \%$ & $81.23 \%$ \\
\hline Wage/Salary, Less than 15 Hours/Week & & $0.38 \%$ & $1.31 \%$ & $1.36 \%$ \\
\hline Unemployed & $8.65 \%$ & $4.11 \%$ & $7.03 \%$ & $3.99 \%$ \\
\hline Welfare & $3.02 \%$ & $1.16 \%$ & $10.25 \%$ & $3.27 \%$ \\
\hline Not in the Labor Force & $21.89 \%$ & $5.09 \%$ & $35.47 \%$ & $9.98 \%$ \\
\hline Number of Observations & 269 & 8,009 & 151 & 5,643 \\
\hline
\end{tabular}

Source: 1996, 2001 and 2004 panels Survey of Income and Program Participation (SIPP). 